\title{
Food sources, behaviour, and distribution of hydrothermal vent shrimps at the Mid-Atlantic Ridge
}

\author{
A.V. Gebruk* ${ }^{\dagger}$, E.C. Southward*, H. Kennedy ${ }^{\ddagger}$ and A.J. Southward*ో \\ * Marine Biological Association, The Laboratory, Citadel Hill, Plymouth, PL1 2PB. ${ }^{\dagger}$ P.P. Shirshov Institute of Oceanology, Russian \\ Academy of Sciences, Nakhimovsky pr. 36, Moscow, 117851, Russia. ${ }^{\ddagger}$ School of Ocean Sciences, University of Wales-Bangor, Menai \\ Bridge, Anglesey, LL59 5EY. ${ }^{\int}$ Corresponding author, e-mail: 100721.3720@compuserve.com
}

Five species of bresilioid shrimp were investigated at seven hydrothermal sites on the Mid-Atlantic Ridge: Menez Gwen, Lucky Strike, Rainbow, Broken Spur, TAG, Snake Pit and Logatchev. Samples were prepared for analysis of stable isotopes, elemental composition and lipids. Shrimp behaviour was observed from the submersible 'Alvin' and in the laboratory aboard RV 'Atlantis'. The distribution and zonation of the shrimp species was recorded. Juvenile shrimp of all species arrive at the vents carrying reserves of photosynthetic origin, built-up in the pelagic larval stages. These reserves are used while the shrimp metamorphose to the adult form and, in Rimicaris exoculata and Chorocaris chacei, while they develop epibiotic bacteria supporting structures, the modified mouthparts and the inside of the carapace. The main food of adult $R$. exoculata is filamentous bacteria that grow on these structures. The intermediate sizes of $C$. chace $i$ also feed on such bacteria, but the final stage gets some food by scavenging or predation. Mirocaris species scavenge diverse sources; they are not trophically dependent on either $R$. exoculata or mussels. Adults of Alvinocaris markensis are predators of other vent animals, including $R$. exoculata. The dense swarms of $R$. exoculata, with their exosymbionts, can be compared to endosymbiont-containing animals such as Bathymodiolus and the vestimentiferan tube-worms of the Pacific vents. Such associations, whether endo- or ectosymbiotic, may be necessary for the development of flourishing communities at hydrothermal vents.

\section{INTRODUCTION}

Exploration of hydrothermal vents in the Atlantic Ocean discovered abundant populations of shrimp and there has been much discussion of their role in the community and their food source (Rona et al., 1986; Williams \& Rona, 1986). Hydrothermal communities in the Pacific Ocean are supported by invertebrates that harbour endosymbiotic chemosynthetic bacteria, regarded as 'primary producers' (Fisher, 1990, 1996; Childress \& Fisher, 1992;). Although deep-water pelagic shrimps are usually carnivores (Omori, 1974), by analogy with Pacific vent communities, it was anticipated that the dominant shrimp at the Mid-Atlantic Ridge (MAR) would harbour endosymbiotic bacteria (Gal'chenko et al., 1989), but no evidence was found. Gut contents, lipopolysaccharide analyses and stable isotope assays suggested that the shrimp ingested bacteria (Van Dover et al., 1988). A particular problem was the high density of the shrimp aggregations compared with the areas of bacterial mats. It is difficult to visualize how large numbers of shrimp could be sustained by grazing on such mats or by filtration of suspended particles. An alternative food source for the shrimp might be bivalve molluscs that rely on endosymbiotic bacteria; these are abundant at some vents, but absent or rare at two sites (TAG, Broken Spur) where shrimp are dominant. The question arises whether the food chain at the MAR is different from other vent ecosystems (Gebruk et al., 1997a).

In reviewing theories of hydrothermal shrimp nutrition, Van Dover (1995), Gebruk et al. (1997a) and Polz et al. (1998) discussed the dietary importance of the bacterial filaments that grow on the mouthparts and the under surface of the carapace, especially in Rimicaris exoculata. Casanova et al. (1993) suggested that shrimp might absorb dissolved organic matter (DOM) from the bacteria, while Polz et al. (1998) proposed that autotrophic bacteria in the gut might contribute to nutrition.

Vent animals are difficult to investigate experimentally, and most evidence about MAR shrimp nutrition comes from chemical, biochemical and stable isotope analyses. We are able to contribute to the investigation of this problem, using new data from a unique set of samples obtained from all the known hydrothermal areas on the MAR (Figure 1), in the depth range $750-3700 \mathrm{~m}$. Samples were taken for stable isotope analysis, lipid analysis, and elemental analysis. Observations on behaviour and microscale distribution of shrimp were made in situ and in the laboratory. In addition to $R$. exoculata, four other shrimp species were investigated, including different ages. The investigations tested several hypotheses, including the role of epibiotic bacteria, input of photosynthetically derived carbon, effect of age and the influence of depth and differing vent environments.

\section{MATERIALS AND METHODS}

\section{Sampling}

Collections were made from the submersible 'Alvin', operating from the RV 'Atlantis', from 29 June to 27 July 1997, at seven sites (Figure 1, Table 1). Most samples were taken with a suction sampler that held its catch inside a perspex cylinder, and the shrimps remained alive until 


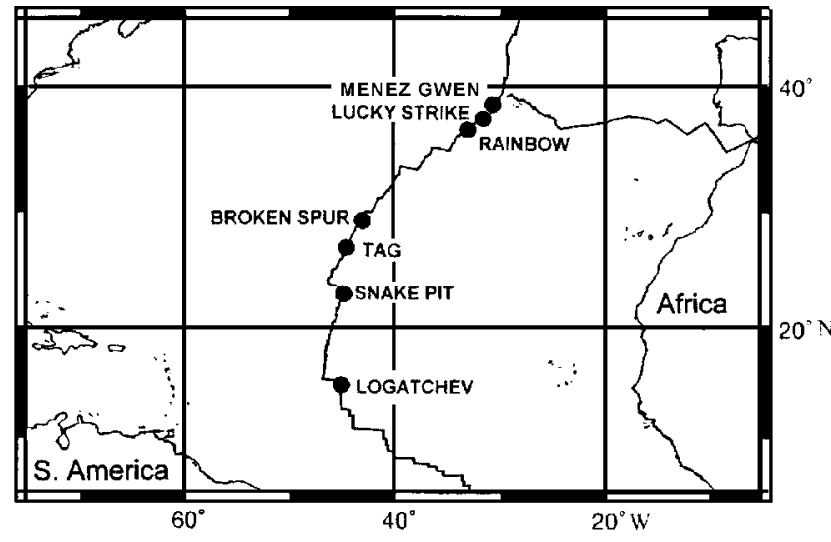

Figure 1. The hydrothermal vent sites along the MidAtlantic Ridge, sampled for bresilioid shrimp on cruise MAR 97.

transferred to the ship. The water from the slurp guns at Lucky Strike showed dissolved sulphide of the order of 0.5 to $5 \mu \mathrm{M}$, indicating some retention of ambient water during the ascent. A few samples were taken with a small net operated by the manipulator arm, placed in an insulated, but unsealed container (biobox) until return to the ship; these shrimp were less viable. Shrimps were sorted into species, transferred to cooled surface seawater and kept in a cool room at $14^{\circ} \mathrm{C}$, or a refrigerator at $4^{\circ} \mathrm{C}$. Representative individuals were preserved in $4 \%$ formol or $70 \%$ ethanol, and the rest measured for total length (rostrum to telson, (TL)). Some workers on Rimicaris exoculata (e.g. Polz et al., 1998) have employed carapace length (CL) hence we measured both total length and carapace length of 17 specimens from Broken Spur and
TAG for comparison. The regression of CL over TL was $\mathrm{y}=0.6417+0.3667 \mathrm{x}$, for a correlation coefficient of 0.95 .

Selected tissues, usually abdominal muscle, from measured specimens were divided into three subsamples, for drying, lipid preservation and freezing for genetic analysis. The lipid analyses and the genetic results are being reported elsewhere (Pond et al., 2000a,b; Shank et al., 1998). Some specimens were dissected into body components, analysed separately. Very small specimens were used whole. Tissues and whole shrimp were dried in aluminium foil boats at $60^{\circ} \mathrm{C}$, then wrapped in foil and stored in a refrigerator. At Plymouth the dry samples were ground in a ball-mill, and the powder stored in glass vials.

\section{Carbon and nitrogen stable isotope analysis}

Subsamples of the dried and ground tissue were acidified in $2 \mathrm{~N} \mathrm{HCl}$ to remove any carbonates and re-dried at $40^{\circ} \mathrm{C}$. The samples were loaded into small precombusted quartz tubes along with copper, precombusted copper oxide and silver foil. These tubes were then loaded into large precombusted quartz tubes, evacuated and sealed. The samples were combusted at $910^{\circ} \mathrm{C}$ for $3 \mathrm{~h}$ and allowed to cool slowly overnight. Resulting $\mathrm{CO}_{2}$ and $\mathrm{N}_{2}$ were separated cryogenically. The $\mathrm{N}_{2}$ collected was analysed immediately, the $\mathrm{CO}_{2}$ was frozen into small glass tubes and flame-sealed until analysis. Both gases were analysed on a VG SIRA II mass spectrometer. Results are expressed relative to PDB and atmospheric nitrogen standards in the usual notation. Precision of an internal laboratory substandard was $0.05 \%$.

Table 1. 'Atlantis' cruise 3, legs 2 and 3, 1997. Station list for this investigation. Temperature is for ambient seawater.

\begin{tabular}{|c|c|c|c|c|c|c|c|c|c|c|}
\hline $\begin{array}{l}\text { Dive } \\
\text { station }\end{array}$ & Date & Site & Latitude & Longitude & $\begin{array}{l}\text { Depth } \\
\mathrm{m}\end{array}$ & $\begin{array}{l}\text { Isotope } \\
\text { samples }\end{array}$ & $\begin{array}{l}\text { Lipid } \\
\text { samples }\end{array}$ & $\begin{array}{l}\mathrm{C}: \mathrm{N}: \mathrm{S} \\
\text { samples }\end{array}$ & $\begin{array}{l}\text { Temp. } \\
\left({ }^{\circ} \mathrm{C}\right)\end{array}$ & Species of shrimp sampled \\
\hline 3114 & 29.06 .97 & Lucky Strike & $37^{\prime} 17^{\circ} \mathrm{N}$ & $32^{\prime} 16^{\circ} \mathrm{W}$ & 1727 & 3 & nd & nd & 4.5 & none \\
\hline 3115 & 30.06 .97 & Lucky Strike & $37^{\prime} 17^{\circ} \mathrm{N}$ & $32^{\prime} 16^{\circ} \mathrm{W}$ & 1719 & 15 & nd & nd & 4.5 & C. chacei, M. fortunata \\
\hline 3117 & 07.07 .97 & Menez Gwen & $37^{\prime} 50.474^{\circ} \mathrm{N}$ & $31^{\prime} 31.366^{\circ} \mathrm{W}$ & 857 & 4 & 4 & 3 & 8.8 & M. fortunata \\
\hline 3118 & 08.07 .97 & Lucky Strike & $37^{\prime} 17.51^{\circ} \mathrm{N}$ & $32^{\prime} 16.66^{\circ} \mathrm{W}$ & 1719 & 7 & 5 & 3 & 4.5 & C. chacei, M. fortunata \\
\hline 3119 & 09.07 .97 & Lucky Strike & $37^{\prime} 17.394^{\circ} \mathrm{N}$ & $32^{\prime} 16.672^{\circ} \mathrm{W}$ & 1721 & 2 & 6 & 3 & 4.5 & C. chacei, M.fortunata \\
\hline 3120 & 10.07 .97 & Lucky Strike & $37^{\prime} 17.629^{\circ} \mathrm{N}$ & $32^{\prime} 16.532^{\circ} \mathrm{W}$ & 1733 & 10 & 11 & 5 & 4.5 & $\begin{array}{l}\text { R. exoculata, C. chacei, } \\
\text { M.fortunata }\end{array}$ \\
\hline 3121 & 11.07 .97 & Rainbow & $36^{\prime} 13.89^{\circ} \mathrm{N}$ & $33^{\prime} 54.15^{\circ} \mathrm{W}$ & 2350 & 2 & 2 & 2 & 3.7 & $M$. fortunata \\
\hline 3122 & 12.07 .97 & Rainbow & $36^{\prime} 14.030^{\circ} \mathrm{N}$ & $33^{\prime} 54.065^{\circ} \mathrm{W}$ & 2305 & 6 & 6 & 4 & 3.7 & R. exoculata, M. fortunata \\
\hline 3123 & 15.07 .97 & Broken Spur & $29^{\prime} 09.976^{\circ} \mathrm{N}$ & $43^{\prime} 10.394^{\circ} \mathrm{W}$ & 3060 & 6 & 9 & 5 & 3 & R. exoculata, M. fortunata \\
\hline 3124 & 16.07 .97 & Broken Spur & $29^{\prime} 10.015^{\circ} \mathrm{N}$ & $43^{\prime} 10.423^{\circ} \mathrm{W}$ & 3056 & 4 & 5 & 3 & 3 & $\begin{array}{l}\text { R. exoculata, C. chacei, } \\
\text { M.fortunata, M. keldyshi }\end{array}$ \\
\hline 3125 & 17.07 .97 & Broken Spur & $29^{\prime} 10.008^{\circ} \mathrm{N}$ & $43^{\prime} 10.400^{\circ} \mathrm{W}$ & 3056 & 3 & 3 & 3 & 3 & R. exoculata, C. chacei, \\
\hline 3126 & 19.07 .97 & TAG & $26^{\prime} 08.141^{\circ} \mathrm{N}$ & $44^{\prime} 49.543^{\circ} \mathrm{W}$ & 3655 & 4 & 5 & 2 & 2.8 & R. exoculata \\
\hline 3127 & 20.07 .97 & TAG & $26^{\prime} 08.184^{\circ} \mathrm{N}$ & $44^{\prime} 49.543^{\circ} \mathrm{W}$ & 3643 & 4 & 4 & 2 & 2.8 & $\begin{array}{l}\text { R. exoculata, C. chacei, } \\
\text { M. keldyshi, A. markensis }\end{array}$ \\
\hline 3128 & 21.07 .97 & Snake Pit & $23^{\prime} 22.060^{\circ} \mathrm{N}$ & $44^{\prime} 56.987^{\circ} \mathrm{W}$ & 3560 & 4 & 5 & 4 & 2.4 & $\begin{array}{l}\text { R. exoculata, C. chacei, } \\
\text { M. keldyshi, A. markensis }\end{array}$ \\
\hline 3129 & 22.07 .97 & Snake Pit & $23^{\prime} 22.200^{\circ} \mathrm{N}$ & $44^{\prime} 57.042^{\circ} \mathrm{W}$ & 3510 & 5 & 10 & 3 & 2.4 & R. exoculata, A. markensis \\
\hline 3131 & 25.07 .97 & Logatchev & $14^{\prime} 44.937^{\circ} \mathrm{N}$ & $44^{\prime} 58.278^{\circ} \mathrm{W}$ & 3018 & 6 & 9 & 3 & 2.8 & $\begin{array}{l}\text { R. exoculata, C. chacei, } \\
\quad \text { M. keldyshi, A. markensis }\end{array}$ \\
\hline 3132 & 26.07 .97 & Logatchev & $14^{\prime} 44.946^{\circ} \mathrm{N}$ & $44^{\prime} 58.278^{\circ} \mathrm{W}$ & 3011 & 0 & 1 & 0 & 2.8 & M. keldyshi \\
\hline 3133 & 27.07 .97 & Logatchev & $14^{\prime} 45.189^{\circ} \mathrm{N}$ & $44^{\prime} 58.829^{\circ} \mathrm{W}$ & 3038 & 7 & 8 & 5 & 2.8 & C. chacei \\
\hline
\end{tabular}

nd, no data. 


\section{Elemental analysis}

Total carbon and nitrogen in the powdered dried tissues were analysed by R.N. Head, Plymouth Marine Laboratory. Total sulphur was measured by Elemental Microanalysis Ltd, Okehampton, Devon.

\section{Behaviour of shrimps and their micro-scale distribution.}

Video images from each dive were examined for shrimp behaviour and distribution. Detailed observations were made during 'Alvin' Dive 3131 at Irina-2, Logatchev and during 'Alvin' Dive 3123 at the Moose site, Snake Pit. Close-up sequences of up to 15 min were recorded. 'Alvin' video equipment included three-chip and digital cameras. The three-chip camera was equipped with a two-beam laser array to indicate scale. Additional records were made with the observers' own Hi-8 video cameras. The distribution of the shrimp was mapped.

\section{Behaviour of shrimps in the laboratory.}

Recovered shrimps were maintained alive in a small tank of surface seawater (renewed daily) with a simple aerator to stir the water. The tank was in a cooled room, at $14^{\circ} \mathrm{C}$. Indirect lighting from screened fluorescent tubes was used for observation and recording, otherwise the animals were kept in the dark. The activities of the shrimp in the main tank or in smaller plastic boxes were recorded with a Sony Hi-8 video camera with zoom lens. Food items taken from the vent habitat were crushed mussels (Bathymodiolus spp.), shrimp tissues and filamentous bacteria on rock fragments. Artemia nauplii were hatched from eggs.

Observations with a stereomicroscope were made in the ship's laboratory (temperature about $20^{\circ} \mathrm{C}$ ). An Olympus stereomicroscope was fitted with a video camera and a monitor for viewing, and recordings made on SVHS tape. Observations began with animals at $14^{\circ} \mathrm{C}$, but the dishes warmed up and long-term microscopic observation was not possible.

A mixture of glass beads $(70-50 \mu \mathrm{m}$ diameter $)$ and carborundum powder (600 mesh) was used to find out whether the shrimp were picking up particles. This mixture was allowed to settle as an even, light-coloured layer on the bottom of three plastic boxes of seawater. Five juvenile $R$. exoculata, 24-25 mm, long were added to each box and left for 10, 15 and $20 \mathrm{~h}$. As they crawled they left tracks in the particle layer and some of them appeared to be handling the particles with their mouthparts and chelae. The shrimp were then fixed in $4 \%$ SW formol and later transferred to $70 \%$ ethanol to harden the tissues.

\section{Taxonomic status of MAR hydrothermal shrimps}

It is necessary to explain the status of the species investigated, as the taxonomy of some vent shrimp has been confused. There may be at least eight species on the MAR. Experts have agreed on the status of four: Rimicaris exoculata Williams \& Rona, 1986, Chorocaris chacei (Williams \& Rona, 1986), Alvinocaris markensis Williams, 1988 and Mirocaris fortunata (Martin \& Christiansen, 1995). Vereschaka (1997a) separated Mirocaris keldyshi from M. fortunata and we found that fresh specimens could be distinguished morphologically and by colour. These were prepared separately for analysis. Using the same series of samples, Shank et al. (in press) found little genetic difference at the mitochondrial COI gene level, but we choose to treat them separately here. The 'small orange shrimp', that are often abundant among aggregations of $R$. exoculata, have had their status disputed. As first noted by Segonzac et al. (1993) they have features intermediate between Chorocaris and Rimicaris (see also Van Dover, 1995; Creasey et al., 1996; Gebruk et al., 1997a). This 'small orange shrimp' was described as Iorania concordia by Vereshchaka (1996a), and as Rimicaris aurantiaca by Martin et al. (1997). The sample series analysed for isotopes was examined by Shank et al. (1998) using allozymes and mitochondrial DNA sequences (COI and 16S rRNA genes), and no difference was found between adult $R$. exoculata and the 'small orange shrimp'. Dixon et al. (1998) also concluded that this form was genetically identical to $R$. exoculata. Therefore we refer to the small orange form as juvenile $R$. exoculata. There are more species of Alvinocaris than first suspected: two new species are being described from MAR '97 cruise material: Alvinocaris sp.aff. stactophila at Menez Gwen (A.B. Williams \& T.M. Shank, personal communication), and Alvinocaris sp. aff. muricola from Logatchev (A.B. Williams \& A.L. Vereshchaka, personal communication). Another species may be present at Logatchev (Vereshchaka, personal communication). Our analyses refer only to A. markensis.

The taxonomy of bresilioid shrimps at the family level is somewhat uncertain (Van Dover, 1995; Gebruk et al., 1997a). Recently, experts (A.B. Williams, J.W. Martin, F.A. Chace and A.L. Vereshchaka, personal communication) have agreed on the placing of vent/seep related shrimps in the families Alvinocarididae Christoffersen 1986 (Alvinocaris, Rimicaris, Chorocaris and Opapele) and Mirocarididae Vereshchaka 1997a (Mirocaris), separating them from non-vent genera which remain in the family Bresiliidae Calman. All three families are included in the superfamily Bresilioidea Calman (Vereshchaka, 1997a).

\section{RESULTS}

\section{Stable carbon and nitrogen isotope analysis}

Results of the stable isotope analyses are set out in Table 2. The values for each species are summarized separately.

\section{Rimicaris exoculata}

Adult stage $R$. exoculata show a moderate range of $\delta^{13} \mathrm{C}$ values $(-9.97$ to $-14.55 \%$, mean -11.79 ; see Table 2$)$, with no significant variations between vents or depths. The most negative values, -14.55 and $-14.44 \%$, were from specimens of 26 and $29 \mathrm{~mm}$ length, but a $25 \mathrm{~mm}$ specimen had a value of -13.84 and another $26 \mathrm{~mm}$ specimen showed $-11.05 \%$, extending the range for the small adult size group. The larger Rimicaris, those exceeding $45 \mathrm{~mm}$ length, had a narrow range of $\delta^{13} \mathrm{C}$, from -9.97 to $-12.05 \%$ (mean $-11.01 \%$ ). The mouthparts (maxilliped I), densely covered with filamentous bacteria, showed $\delta^{13} \mathrm{C}$ values of -11.45 and $-10.52 \%$, within the range for abdominal issues of the large adults, and close to the mean. Corresponding $\delta^{15} \mathrm{~N}$ values for the maxillipeds with 
Table 2. Five species of hydrothermal vent shrimp. Stable isotope ratios $(G: \mathcal{N})$, and element analysis $(C, \mathcal{N}, S)$.

\begin{tabular}{|c|c|c|c|c|c|c|c|c|}
\hline \multirow[b]{2}{*}{ Site } & \multirow[b]{2}{*}{ Length $(\mathrm{mm})$} & \multicolumn{3}{|c|}{ Stable isotopes } & \multicolumn{4}{|c|}{ Elemental analysis } \\
\hline & & Tissue used & $\delta^{13} \mathrm{C}(\% 0)$ & $\delta^{15} \mathrm{~N}(\%)$ & Tissue used & Carbon $(\%)$ & Nitrogen $(\%)$ & Sulphur $(\%)$ \\
\hline \multicolumn{9}{|c|}{ Rimicaris exoculata: adult form } \\
\hline LS & 58.00 & $\mathrm{a}$ & -11.13 & 7.45 & & nd & nd & nd \\
\hline $\mathrm{LS}$ & 58.00 & $\mathrm{a}$ & -11.10 & 7.87 & $\mathrm{a}$ & 35.08 & 10.57 & 1.13 \\
\hline LS & 58.00 & $\mathrm{~m}$ & -11.45 & 5.57 & c & 27.26 & 6.86 & 2.00 \\
\hline $\mathrm{RB}$ & 49.00 & $\mathrm{a}$ & -10.09 & 7.43 & $\mathrm{a}$ & 34.84 & 10.53 & 1.05 \\
\hline $\mathrm{RB}$ & 53.00 & $\mathrm{~m}$ & -10.52 & 6.54 & & nd & nd & nd \\
\hline $\mathrm{RB}$ & 45.00 & $\mathrm{a}$ & -9.97 & 7.98 & a & 34.98 & 10.69 & 1.09 \\
\hline BS & 57.00 & $\mathrm{a}$ & -10.75 & 7.64 & $\mathrm{c}$ & 38.89 & 10.08 & 0.84 \\
\hline $\mathrm{BS}$ & 26.00 & $\mathrm{a}$ & -14.55 & 6.18 & c & 35.68 & 6.82 & 2.00 \\
\hline TAG & 26.00 & $\mathrm{a}$ & -11.05 & 5.55 & & nd & nd & nd \\
\hline TAG & 52.00 & $\mathrm{a}$ & -11.47 & 6.57 & c & 40.98 & 8.58 & 0.53 \\
\hline $\mathrm{SP}$ & 31.00 & $\mathrm{a}$ & -12.70 & 5.93 & c & 41.00 & 8.83 & 1.14 \\
\hline SP & 25.00 & $\mathrm{a}$ & -13.84 & 6.08 & c & 41.37 & 6.45 & 1.65 \\
\hline SP & 57.00 & $\mathrm{a}$ & -12.05 & 6.88 & c & nd & nd & nd \\
\hline LOG & 29.00 & $\mathrm{a}$ & -14.44 & 5.84 & c & 34.30 & 8.14 & 0.68 \\
\hline \multicolumn{9}{|c|}{ Rimicaris exoculata: juveniles } \\
\hline BS & 18.00 & $\mathrm{a}$ & -18.07 & 5.68 & c & 34.69 & 6.84 & 0.93 \\
\hline $\mathrm{BS}$ & 26.00 & $\mathrm{a}$ & -16.81 & 4.73 & c & 50.68 & 5.89 & 0.56 \\
\hline BS & 25.00 & $\mathrm{a}$ & -15.79 & 4.48 & c & 49.85 & 5.79 & 0.95 \\
\hline BS & 28.00 & $\mathrm{a}$ & -15.61 & nd & & nd & nd & nd \\
\hline TAG & 26.00 & $\mathrm{a}$ & -16.13 & 4.50 & & nd & nd & nd \\
\hline TAG & 25.00 & $\mathrm{a}$ & -17.44 & 4.69 & $\mathrm{c}$ & 50.16 & 5.94 & 0.45 \\
\hline $\mathrm{SP}$ & 28.00 & $\mathrm{a}$ & -16.18 & 3.94 & $\mathrm{c}$ & 54.55 & 4.17 & 1.64 \\
\hline LOG & 26.00 & $\mathrm{a}$ & -16.11 & 5.15 & c & 53.69 & 4.75 & 0.30 \\
\hline \multicolumn{9}{|c|}{ Chorocaris chacei } \\
\hline LS & 23.00 & $\mathrm{a}$ & -12.78 & 6.07 & & nd & nd & nd \\
\hline $\mathrm{LS}$ & 40.00 & $\mathrm{a}$ & -12.58 & 6.79 & & nd & nd & nd \\
\hline $\mathrm{LS}$ & 40.00 & $\mathrm{~m}$ & -13.76 & 4.07 & & nd & nd & nd \\
\hline $\mathrm{LS}$ & 42.00 & $\mathrm{a}$ & -12.96 & 5.99 & c & 34.30 & 7.19 & 2.10 \\
\hline $\mathrm{LS}$ & 47.00 & $\mathrm{a}$ & -14.85 & 4.75 & $\mathrm{a}$ & 32.44 & 9.6 & 0.77 \\
\hline $\mathrm{LS}$ & 49.00 & $\mathrm{a}$ & -15.14 & 4.99 & $\mathrm{a}$ & 35.94 & 11.24 & nd \\
\hline $\mathrm{LS}$ & 50.00 & $\mathrm{a}$ & -14.36 & 5.50 & $\mathrm{a}$ & 37.92 & 11.12 & 1.14 \\
\hline LS & 50.00 & $\mathrm{~m}$ & -14.38 & 5.22 & c & 31.79 & 7.67 & 2.52 \\
\hline LS & 45.00 & $\mathrm{a}$ & -12.53 & 7.07 & & nd & nd & nd \\
\hline LS & 32.00 & $\mathrm{a}$ & -11.67 & 7.31 & & nd & nd & nd \\
\hline LS & 32.00 & c & -11.82 & 5.72 & & nd & nd & nd \\
\hline LS & 43.00 & $\mathrm{a}$ & -14.33 & 5.88 & & nd & nd & nd \\
\hline LS & 43.00 & c & -14.07 & 5.34 & & nd & nd & nd \\
\hline $\mathrm{LS}$ & 43.00 & ex & -14.31 & 4.23 & & nd & nd & nd \\
\hline $\mathrm{LS}$ & 43.00 & $\mathrm{~m}$ & -14.35 & 4.15 & & nd & nd & nd \\
\hline $\mathrm{LS}$ & 43.00 & s & -14.61 & 4.19 & & nd & nd & nd \\
\hline BS & 48.00 & $\mathrm{a}$ & -13.02 & 8.00 & c & 32.92 & 9.52 & 0.85 \\
\hline BS & 62.00 & $\mathrm{a}$ & -13.61 & 7.98 & $\mathrm{c}$ & 31.90 & 7.62 & 1.01 \\
\hline TAG & 16.00 & $\mathrm{t}$ & -15.93 & 5.58 & & nd & nd & nd \\
\hline TAG & 43.00 & $\mathrm{a}$ & -15.56 & 7.32 & c & 42.82 & 9.03 & 0.71 \\
\hline SP & 18.00 & $\mathrm{t}$ & -18.03 & 5.40 & & nd & nd & nd \\
\hline $\mathrm{SP}$ & 68.00 & $\mathrm{a}$ & -13.44 & 8.03 & $\mathrm{a}$ & 35.66 & 11.55 & 0.46 \\
\hline LOG & 16.00 & t & -16.79 & 5.82 & & nd & nd & nd \\
\hline LOG & 54.00 & $\mathrm{a}$ & -13.28 & 7.71 & $\mathrm{a}$ & 35.80 & 11.61 & 0.55 \\
\hline \multicolumn{9}{|c|}{ Alvinocaris markensis } \\
\hline TAG & 58.00 & $\mathrm{a}$ & -17.89 & 9.19 & $\mathrm{a}$ & nd & nd & nd \\
\hline $\mathrm{SP}$ & 52.00 & $\mathrm{a}$ & -15.21 & 7.54 & $\mathrm{a}$ & 37.34 & 8.83 & 0.50 \\
\hline LOG & 28.00 & $\mathrm{a}$ & -21.17 & 3.65 & $\mathrm{a}$ & nd & nd & nd \\
\hline
\end{tabular}


Table 2. (Continued).

\begin{tabular}{|c|c|c|c|c|c|c|c|c|}
\hline \multirow[b]{2}{*}{ Site } & \multirow[b]{2}{*}{ Length (mm) } & \multicolumn{3}{|c|}{ Stable isotopes } & \multicolumn{4}{|c|}{ Elemental analysis } \\
\hline & & Tissue used & $\delta^{13} \mathrm{C}(\%$ o $)$ & $\delta^{15} \mathrm{~N}(\% \mathbf{0})$ & Tissue used & Carbon (\%) & Nitrogen $(\%)$ & Sulphur $(\%)$ \\
\hline \multicolumn{9}{|c|}{ Mirocaris fortunata } \\
\hline MG & 14 & & nd & nd & c & 36.71 & 7.28 & 0.67 \\
\hline MG & 14 & $\mathrm{t}$ & -19.32 & 6.73 & & nd & nd & nd \\
\hline MG & 18 & & nd & nd & $\mathrm{t}$ & 34.16 & 9.52 & 0.88 \\
\hline MG & 23 & $\mathrm{a}$ & -14.82 & 6.4 & & nd & nd & nd \\
\hline MG & 29 & $\mathrm{a}$ & -19.73 & 4.1 & c & 36.02 & 8.24 & 1.04 \\
\hline $\mathrm{LS}$ & 17 & $\mathrm{t}$ & -22.06 & 2.16 & & nd & nd & nd \\
\hline $\mathrm{LS}$ & 18 & & nd & nd & $\mathrm{t}$ & 35.41 & 9.52 & 1 \\
\hline $\mathrm{LS}$ & 28 & $\mathrm{a}$ & -21.61 & 1.34 & c & 30.11 & 8.02 & 1.23 \\
\hline $\mathrm{LS}$ & 26 & $\mathrm{a}$ & -14.45 & 6.65 & c & 37.01 & 8.04 & 1.15 \\
\hline $\mathrm{LS}$ & 31 & $\mathrm{a}$ & -12.16 & 7.07 & $\mathrm{a}$ & 34.11 & 10.56 & 0.96 \\
\hline $\mathrm{RB}$ & 17 & $\mathrm{t}$ & -12.3 & 8.4 & & 39.37 & 7.78 & 1.02 \\
\hline $\mathrm{RB}$ & 20 & & nd & nd & $\mathrm{a}$ & 34.93 & 10.46 & 0.98 \\
\hline $\mathrm{RB}$ & 22 & $\mathrm{a}$ & -15.89 & 6.37 & c & 29.26 & 6.94 & 1.27 \\
\hline $\mathrm{RB}$ & 20 & $\mathrm{a}$ & -11.66 & 7.41 & $\mathrm{a}$ & 33.69 & 7.82 & 1.68 \\
\hline $\mathrm{RB}$ & 23 & $\mathrm{a}$ & -11.13 & 7.93 & c & 39.73 & 8.04 & 0.88 \\
\hline BS & 23 & $\mathrm{a}$ & -11.68 & 7.2 & c & 34.08 & 7.55 & 3.37 \\
\hline BS & 30 & $\mathrm{a}$ & -10.46 & 7.69 & c & 33.62 & 7.23 & 3.86 \\
\hline \multicolumn{9}{|c|}{ Mirocaris keldyshi } \\
\hline $\mathrm{BS}$ & 24 & $\mathrm{a}$ & -11.38 & 7.87 & $\mathrm{a}$ & 29.89 & 7.12 & 3.1 \\
\hline $\mathrm{BS}$ & 28 & $\mathrm{a}$ & -12.05 & 7.67 & & nd & nd & nd \\
\hline TAG & 30 & $\mathrm{a}$ & -15.50 & 8.00 & $\mathrm{a}$ & 41.02 & 6.36 & 0.57 \\
\hline $\mathrm{SP}$ & 20 & $\mathrm{a}$ & -12.12 & 8.56 & $\mathrm{c}$ & 32.33 & 8.40 & 1.06 \\
\hline $\mathrm{SP}$ & 32 & $\mathrm{a}$ & -11.89 & 7.02 & c & 37.91 & 8.68 & 0.94 \\
\hline LOG & 14 & $\mathrm{t}$ & -21.71 & 6.66 & & nd & nd & nd \\
\hline LOG & 26 & $\mathrm{a}$ & -15.45 & 6.05 & c & 35.24 & 7.57 & 0.61 \\
\hline
\end{tabular}

The vent sites are coded: MG, Menez Gwen; LS, Lucky Strike; RB, Rainbow; BS, Broken Spur; SP, Snake Pit; LOG, Logatchev. Tissues used are noted: a, abdominal muscle; c, cephalothorax; m, mouthparts + bacteria; nd, no data.
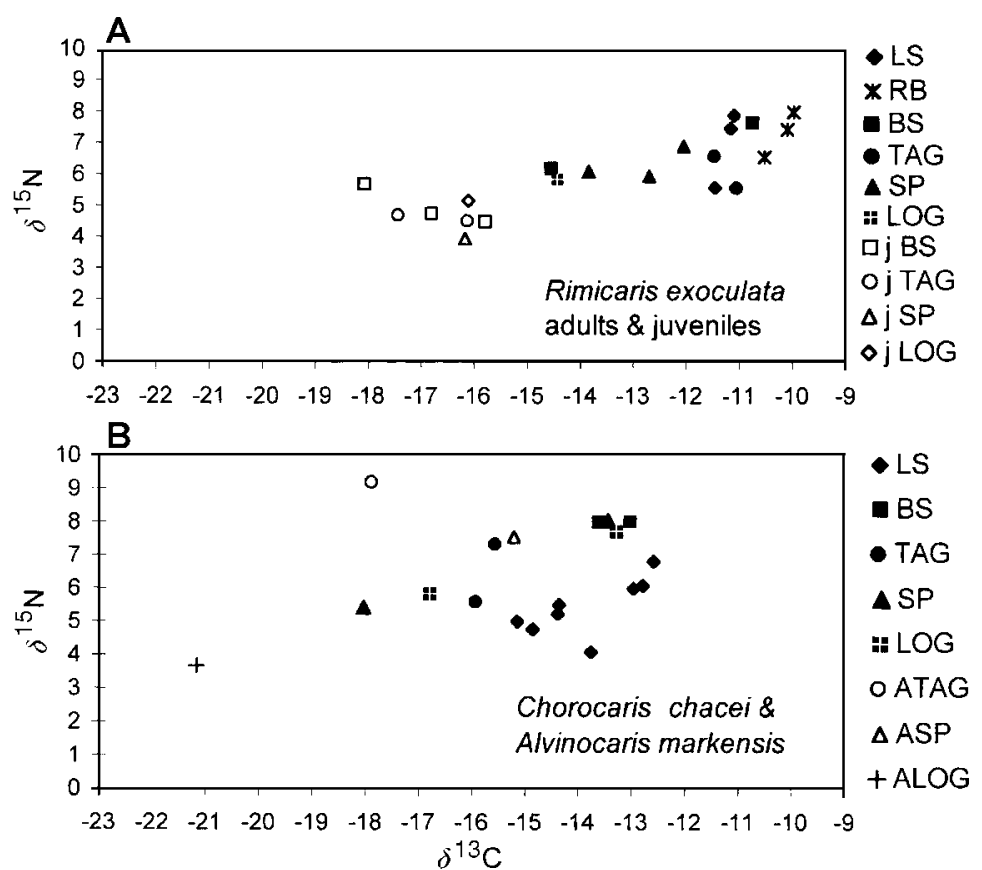

Figure 2. (A) Rimicaris exoculata, adults and juveniles. Plot of $\delta^{15} \mathrm{~N}$ against $\delta^{13} \mathrm{C}$ for individual specimens. The juvenile $R$. exoculata are indicated by open symbols and the prefix $\mathrm{j}$ to the site abbreviation. (B) Chorocaris chacei and Alvinocaris markensis. Plot of $\delta^{15} \mathrm{~N}$ against $\delta^{13} \mathrm{C}$ for individual specimens. Alvinocaris specimens are indicated by open symbols and the prefix A to the site abbreviation. Vent sites are shown abbreviated: MG, Menez Gwen; LS, Lucky Strike; RB, Rainbow; BS, Broken Spur; TAG, full name; SP, Snake Pit; LOG, Logatchev. 
bacteria were 5.57 and $6.54 \%$, at the lower end of the range for adults (5.55-7.98\%). These values for the maxillipeds and bacterial coatings are from Lucky Strike specimens; surprisingly, the abdominal tissues of the same specimens are less depleted in ${ }^{13} \mathrm{C}(-11.1$ to $-9.97 \%$ o but are enriched in ${ }^{15} \mathrm{~N}$ (7.43 to $7.98 \%$ )

Juveniles of R. exoculata differed remarkably in $\delta^{13} \mathrm{C}$ from the adults. There was a narrow range of $\delta^{13} \mathrm{C}$, compared to all other shrimp, from -18.07 to $-15.61 \%$ (mean $-16.84 \%$ ). The difference is highly significant (ANOVA, $P<0.001$ ). There is also a significant difference $(P<0.001)$ in the $\delta^{15} \mathrm{~N}$ values of the two groups; the juveniles have the narrowest range of all shrimp analysed, and the mean $\delta^{15} \mathrm{~N}(4.96 \%$ o) is not far from that for mixed oceanic plankton. The juveniles form a distinct cluster when the $\delta^{15} \mathrm{~N}$ values are plotted against the $\delta^{13} \mathrm{C}$ results (Figure 2). The strongest sign of photosynthetic material $\left(\delta^{13} \mathrm{C}-18.07 \%\right)$ was in the smallest juvenile $(18 \mathrm{~mm})$. After arrival at vent habitats the young rapidly change in shape and their mouthparts enlarge (Vereshchaka, 1997b). There is a gradual increase of bacterial abundance on the mouthparts, from a small amount at the $18-21 \mathrm{~mm}$ stage to a significant amount at $25-26 \mathrm{~mm}$.

\section{Chorocaris chacei}

Chococaris chacei $\delta^{13} \mathrm{G}$ varied from -12.58 to $-18.03 \%$. (Table 2). Larger specimens $(>40 \mathrm{~mm})$ were least depleted (mean $-13.88 \%$ ), but on average were $2 \%$ more depleted than large $R$. exoculata. The greatest depletion $(-18.03 \%$ ) was shown by a specimen of $18 \mathrm{~mm}$ length, but the two smallest specimens $(16 \mathrm{~mm})$ were less depleted (-16.79 and -15.93\%o). The mouthparts carrying filamentous bacteria had $\delta^{13} \mathrm{C}$ of -13.76 and $-14.38 \%$, more depleted than the same appendages in $R$. exoculata. The $\delta^{15} \mathrm{~N}$ values, from 4.07 to $8.03 \%$, correspond to the total range for $R$. exoculata, taking into account juveniles as well as adults.

When Chorocaris chacei $\delta^{15} \mathrm{~N}$ values are plotted against $\delta^{13} \mathrm{G}$ some differences from $R$. exoculata can be seen (Figure 2B). The eight specimens from Lucky Strike vary, but form a cluster with generally lower $\delta^{15} \mathrm{~N}$ values than those from the deeper sites, Broken Spur, TAG, Snake Pit and Logatchev. Specimens from these latter sites have a more nearly linear relationship of $\delta^{15} \mathrm{~N}$ to $\delta^{13} \mathrm{C}$, and include the four highest $\delta^{15} \mathrm{~N}$ values for $C$. chacei (7.71-8.03). Some additional specimens from Lucky Strike were further dissected (Table 2). The abdominal tissues differ little in $\delta^{13} \mathrm{C}$ from the rest of the body, but the $\delta^{15} \mathrm{~N}$ values are higher for abdominal tissues than other parts, especially the limbs and the exoskeleton. This must be borne in mind when comparing values for whole specimens with values for abdominal muscle.

\section{Alvinocaris markensis}

Only three specimens of Alvinocaris markensis were available, each from a different site (Table 2). The carbon and nitrogen results differed slightly in the larger specimens, $58 \mathrm{~mm}$ long from TAG $\left(\delta^{13} \mathrm{C}-17.89 \%\right.$ and $\delta^{15} \mathrm{~N} 9.19 \%$ ) and $52 \mathrm{~mm}$ long from Snake Pit $\left(\delta^{13} \mathrm{C}-15.21 \%\right.$ and $\delta^{15} \mathrm{~N}$ $7.54 \%$ o). A greater difference was found for the small specimen $(28 \mathrm{~mm})$ from Logatchev $\left(\delta^{13} \mathrm{C}-21.17 \%\right.$ and $\delta^{15} \mathrm{~N} 3.65 \%$ ), indicating a different food source. Inclusion
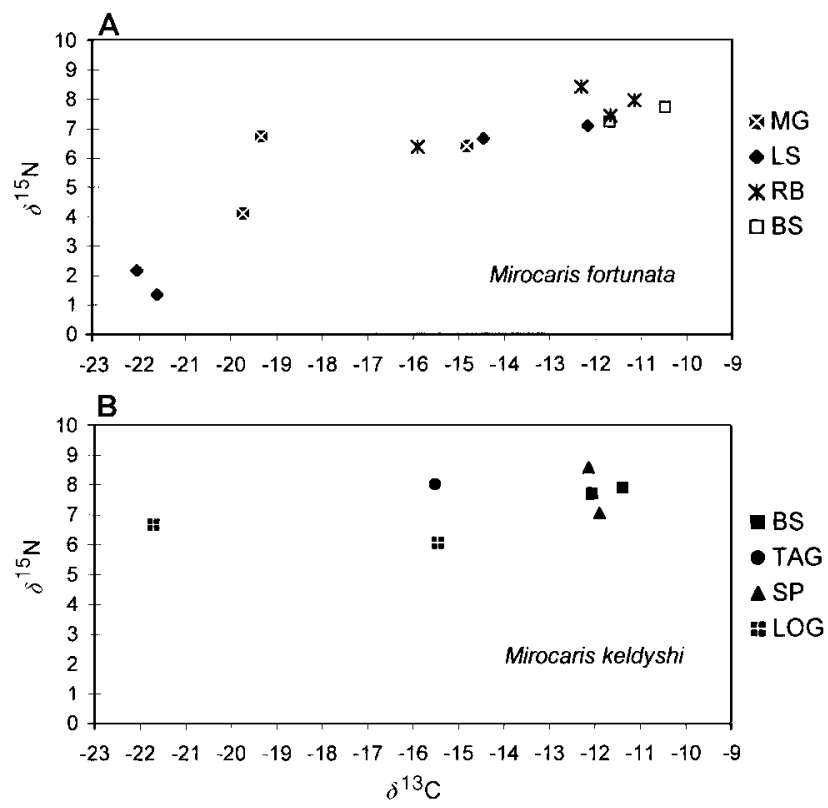

Figure 3. (A) Mirocaris fortunata. Plot of $\delta^{15} \mathrm{~N}$ against $\delta^{13} \mathrm{C}$ for individual specimens. (B) Mirocaris keldyshi. Plot of $\delta^{15} \mathrm{~N}$ against $\delta^{13} \mathrm{C}$ for individual specimens. Vent sites are shown abbreviated: MG, Menez Gwen; LS, Lucky Strike; RB, Rainbow; BS, Broken Spur; TAG, full name; SP, Snake Pit; LOG, Logatchev.

of these values for A. markensis in the plot (Figure 2B) emphasizes the great individual variation.

\section{Mirocaris}

Both species of Mirocaris showed wide ranges of $\delta^{13} \mathrm{C}$, $-10.46 \%$ to $-22.06 \%$ for Mirocaris fortunata and $-11.38 \%$ to $-21.71 \%$ for M. keldyshi (Table 2). There is no significant relationship to size, but a relationship to depth is evident. $M$. fortunata from the two shallower sites, Menez Gwen and Lucky Strike, had mean $\delta^{13} \mathrm{C}$ values of -17.96 and $-17.57 \%$ o respectively. There was much less depletion at the slightly deeper Rainbow site (mean $-12.75 \%$ ) and the deeper Broken Spur site (mean $-11.07 \%$ ). M. keldyshi co-occurred with $M$. fortunata at Broken Spur and had similar $\delta^{13} \mathrm{C}$ values there, but individuals from Logatchev showed much more depletion of ${ }^{13} \mathrm{C}$ and lower $\delta^{15} \mathrm{~N}$ values. The slight difference in mean $\delta^{15} \mathrm{~N}$ between the two species, $M$. keldyshi at $7.4 \%$ and M. fortunata at $6.1 \%$, is not statistically significant.

Plots of $\delta^{15} \mathrm{~N}$ against $\delta^{13} \mathrm{C}$ (Figure 3) emphasize the different trends in isotope ratios in Mirocaris spp. Much of the variation in $M$. fortunata is due to inclusion of depleted specimens from Lucky Strike dive 3118, at a location where samples of the bacterial mats showed greater depletion of ${ }^{13} \mathrm{C}$ and ${ }^{15} \mathrm{~N}$ (see section below).

\section{Free-living bacteria}

Samples of free-living bacteria that contained enough material for isotope assay were available only for Lucky Strike and Logatchev. They came from mats of filamentous bacteria on the mussel beds, close to aggregations of $R$. exoculata and where there were considerable numbers of Mirocaris spp. Two batches from Lucky Strike gave $\delta^{13} \mathrm{C}$ values of $-29.39 \%$ and $-27.64 \%$, compared with $-23.44 \%$ at Logatchev; these samples were too small to 
measure nitrogen isotopes. A larger sample from Lucky Strike, in which the bacteria were mixed with detritus, showed a comparable value for $\delta^{13} \mathrm{C}(-25.69 \%$ ) but an extremely low $\delta^{15} \mathrm{~N}$ value $(-7.11 \%$ ). These values for freeliving bacteria differ from those established for the bacteria carried by the shrimp.

\section{Other vent fauna}

A few bivalves were submitted to stable isotope analysis, to gain some idea of the composition of alternative food available to the shrimp. Specimens of Bathymodiolus azoricus from Lucky Strike, had $\delta^{13} \mathrm{C}$ values ranging from -32.42 to $-32.08 \%$, and $\delta^{15} \mathrm{~N}$ values from -13.52 to $-12.22 \%$. The most highly depleted $\delta^{15} \mathrm{~N}$ value $(-13.52 \%)$ was from gill tissue, where the endosymbiotic bacteria live. A mussel from Logatchev differed markedly in isotope ratios $\left(\delta^{13} \mathrm{C}-14.86 \%\right.$ and $\delta^{15} \mathrm{~N} 1.87 \%$ for the foot, $\delta^{13} \mathrm{C}-14.3 \%$ and $\delta^{15} \mathrm{~N} 1.43 \%$ for the gill). A vesicomyid from the clam bed at Logatchev had stable isotope ratios close to those found in vesicomyids from other vent areas $\left(\delta^{13} \mathrm{C}-34.79 \%\right.$ and $\delta^{15} \mathrm{~N} 3.64 \%$ for the foot, $\delta^{13} \mathrm{C}$ $-36.27 \%$ and $\delta^{15} \mathrm{~N} 1.53 \%$ for the gill).

These results need to be judged in the context of data from larger Menez Gwen and Lucky Strike samples studied by Trask \& Van Dover (1999) and Pond et al. (1998). There is a species difference between Lucky Strike (B. azoricus) and Logatchev (B. puteoserpentis), as reported by Von Cosel et al. (1999) and discussed by Maas et al. (1999).

\section{Elemental composition $(C: \mathcal{N}: S)$}

Individual results for all shrimps are presented in Table 2. The high content of carbon and low content of nitrogen in juvenile $R$. exoculata (mean $\mathrm{C}: \mathrm{N}$ ratio 9.18) is striking in comparison to older individuals, which had a mean $\mathrm{C}: \mathrm{N}$ ratio of 4.3 , close to normal for marine life. ANOVA shows this difference to be highly significant $(P<0.001)$. The other species of shrimp show $\mathrm{C}: \mathrm{N}$ ratios like those of older $R$. exoculata ( $\sim 4.3$ ).

Sulphur analyses showed the greatest range $(0.5-4.0 \%)$ and highest mean value $(2.28 \%)$ in $M$. fortunata, which also showed a wide range in carbon isotope ratios. The sulphur range was least $(0.53-2 \%)$ and the mean value lowest $(1.06 \%)$ in $R$. exoculata, a surprising result in view of the predilection of this species for the hottest, and presumably, most sulphurous parts of the vents. The juveniles showed slightly less sulphur (mean $0.80 \%$ ) than the older specimens of $R$. exoculata (mean $1.21 \%$ ), but this was not statistically significant.

\section{Shrimp distribution and behaviour}

Rimicaris exoculata and C. chacei were found at all sites except Menez Gwen, where M. fortunata and Alvinocaris sp. aff. stactophila were collected. A discontinuity exists at Broken Spur. Mirocaris fortunata is present there and at the sites to the north (Menez Gwen, Lucky Strike and Rainbow). Mirocaris keldyshi overlaps with $M$. fortunata at Broken Spur, but is the only species of Mirocaris farther south at TAG, Snake Pit and Logatchev. Bathymodiolus species show a similar discontinuity (Maas et al., 1999).

Shrimp micro-scale distribution patterns depend on the habitat landscape at the various sites.

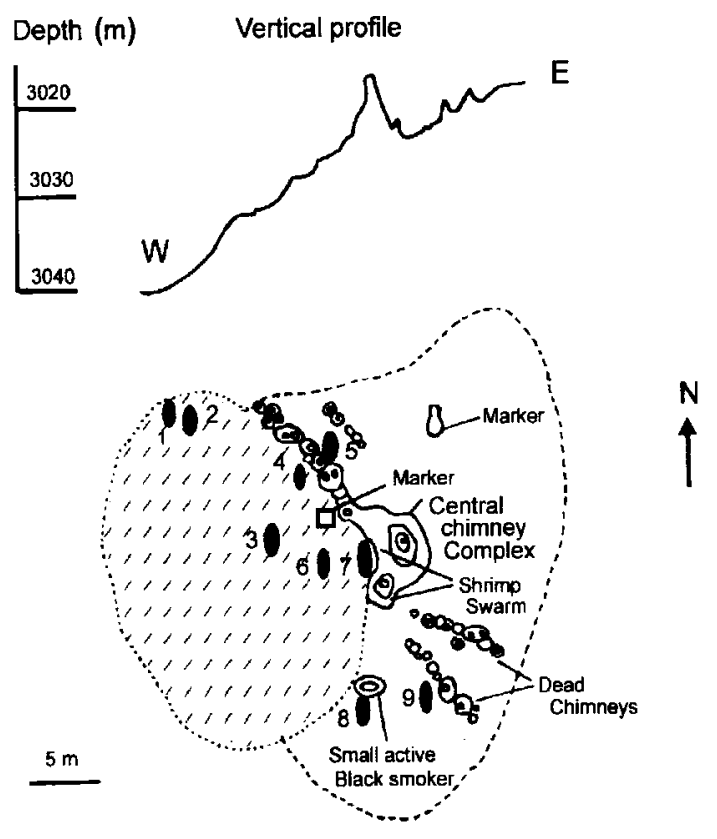

Figure 4. Chart of the Irina-2 complex at Logatchev, with a vertical profile across it. The mussel bed on the west side is shown with diagonal dashes. The chimneys occupy the higher and eastern part of the mound. Places where observations were made on shrimp, as mentioned in the text, are labelled $1-9$.

\section{Logatchev}

Shrimp distribution was studied at nine locations at Irina-2 where the fauna is most diverse (Gebruk et al., 2000). Figure 4 maps the site. The overall pattern was patchy, but two zones could be discerned: (a) a swarm of Rimicaris with strongly pronounced borders, and (b) the mussel bed with $M$. keldyshi.

On the mussel bed $M$. keldyshi was dominant, but patchy, with estimated densities varying from a few individuals per $\mathrm{m}^{2}$ at the edge of the bed (point 1 ) to $80-90$ ind $\mathrm{m}^{-2}$ at point 3 , in small groups of $10-12$ ind at most. Higher densities occurred at the base of the central chimney complex where biomass was high. The greatest density of $M$. keldysh $i$ was at the thickest part of the mussel bed. There were fewer individuals on mussel clusters (points 4 and 5) and fewer still on the wall of the small black smoker (8) where the temperature was slightly elevated. A few occurred on the wall of a small smoker at the base of the central chimney complex (point 6) where the temperature was $23.1{ }^{\circ} \mathrm{C}$. These shrimp were moving actively on the mussel bed, often changing their position.

The central smoker complex was occupied by a swarm of adult $R$. exoculata with distinct patches $(0.3-0.5 \mathrm{~m}$ in diameter) of the juvenile stage. Groups of juvenile $R$. exoculata occurred in zones of diffuse flow where the temperature was $>20^{\circ} \mathrm{C}$. Juveniles were not present in zones of high vent flow or close to black smoke. Shrimps in the swarm remained motionless on the substratum but started swimming when entrained by turbulent water; juveniles were usually less active than adults.

Density of $R$. exoculata, estimated from video frames, was at least 3000 ind $\mathrm{m}^{-2}$ for adults and up to 3500 ind $\mathrm{m}^{-2}$ for juveniles. However, the vertical orientation of the swarm and its thickness (up to $0.4 \mathrm{~m}$ on concave surfaces) make the three dimensional structure very complex, so 


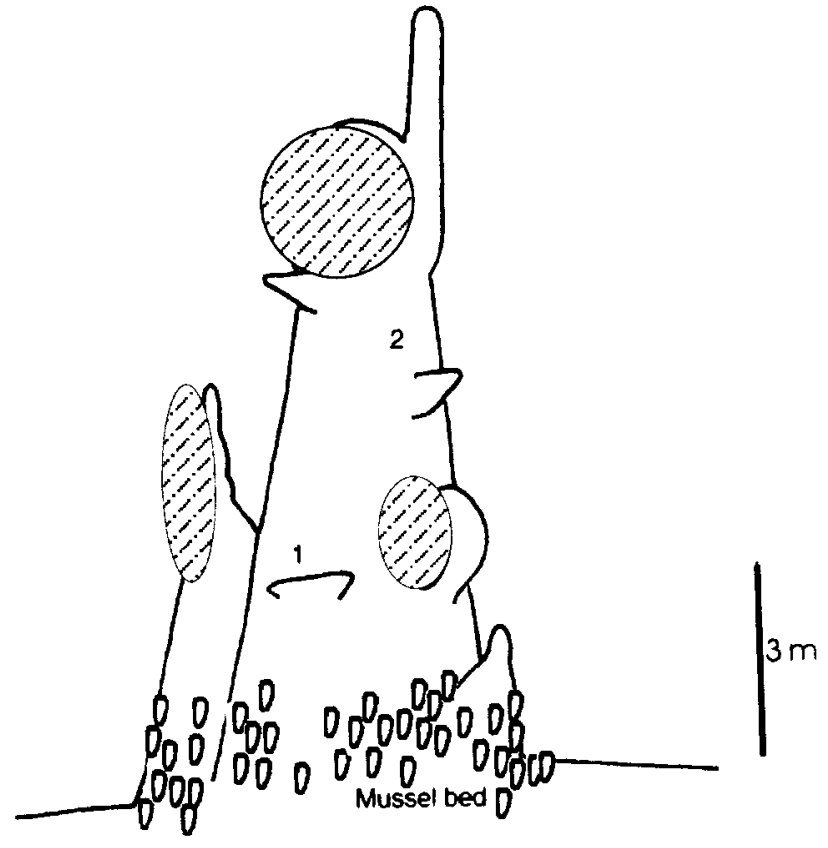

Figure 5. Sketch of the Moose chimney at Snake Pit, with mussels at the base. The swarms of Rimicaris exoculata are delineated with diagonal dots and dashes. Places mentioned in the text are numbered 1 and 2.

estimates of density are conservative. The borders of the swarm were pronounced: density changed from thousands to just a few per $\mathrm{m}^{2}$ over a few tens of centimetres.

Patches of up to 10-15 juvenile shrimp often occurred on the mussel bed. Slurp-gun samples taken at points 3 and 4 contained mostly M. keldyshi and C.chacei, with a few R. exoculata. Adult C. chacei occurred alone or in small groups (34 individuals) within the swarm of $R$. exoculata and on the mussel bed. They were seen scavenging on dead $R$. exoculata but sometimes attacking apparently undamaged shrimps.

\section{Snake Pit}

The distribution of shrimps was studied on a chimney complex at the Moose site, sketched in Figure 5. The main chimney was 9-10 $\mathrm{m}$ high and there was a clear vertical pattern. Swarms of $R$. exoculata, including small groups of juveniles, occurred in regions of diffuse flow on the tops of the main and smaller structures, and on one of the side heads, with densities of about 2500 ind $\mathrm{m}^{-2}$ for both adults and juveniles. Alvinocaris markensis was abundant at the periphery of the swarms, forming groups of 68 individuals at points 1 and 2, with a density of up to 30 ind $\mathrm{m}^{-2}$. Single C. chacei and juveniles were present on the wall of the main structure between points 1 and 2 , but the mussel bed at the base of the main structure and mussel clusters close to it showed mainly juveniles. A slurp-gun sample contained several species: C.chacei (most abundant), A.markensis, R. exoculata and M. keldyshi, the latter two in small numbers. The total shrimp density on the mussel bed was $\sim 40$ ind $\mathrm{m}^{-2}$.

\section{Lucky Strike}

At Lucky Strike C.chacei and M.fortunata were dominant and $R$. exoculata was uncommon. Recordings from dive 3120 at Sintra chimney showed the shrimp reacting to mussel sampling. Chococaris chacei and M.fortunata were moving, separately or in small groups, over the mussels. As the manipulator arm approached, the shrimp kept still or retreated slightly. When a mussel was crushed by the arm and left in situ, individuals of both species moved within $10 \mathrm{~s}$ to the crushed mussel, investigated the broken shell and appeared to feed.

\section{Behaviour of captive shrimp}

Viability

Mirocaris fortunata, C.chacei and juvenile R. exoculata survived at atmospheric pressure for at least a few hours and swam apparently normally. Some lived two or three days, and a few egg-bearing female $M$. fortunata survived a week or longer. Most large R. exoculata died during sorting; survivors lay on their backs or sides moving their limbs weakly and a few lived for $24 \mathrm{~h}$.

\section{Feeding behaviour}

When presented with mussel or shrimp tissue M. fortunata and C.chacei from Lucky Strike touched the material with their antennae, then remained close and appeared to cut it with their chelae. Only one or two individuals at a time were attracted, though there were many in the tank. Pieces of sulphide rock coated with bacterial filaments attracted $M$. fortunata and $C$. chacei, and the shrimp remained for hours in contact with the rough-surfaced rock which was easier to cling to than the aquarium surface. An individual M.fortunata partly consumed a polychaete (Amathys lutzi) that was attached to one of the rock fragments, but filamentous bacteria did not apparently stimulate a feeding response and the visible filaments remained uneaten. Small M. fortunata and $C$. chacei did not attempt to capture living Artemia nauplii when these were provided.

\section{Water currents}

Microscopic observation and video recordings of the cephalothoracic region showed regular beating of the scaphognathites, large flaps on the second maxillae, at 50-100 beats $\mathrm{min}^{-1}$. Water flowed forward through the space under the carapace. Addition of dye trails showed that in M.fortunata and small C. chacei water entered under the postero-ventral border of the carapace, to pass over the gills (attached to the bases of the pereiopods), before passing the mouthparts and emerging below the antennal bases. This is the normal ventilatory current in free-swimming shrimps. Suspended carmine particles appeared to be removed by the mouthparts, indicating the feasibility of filter feeding.

\section{Feeding on surfaces}

Juvenile $R$. exoculata from Snake Pit, TAG and Logatchev swam in the aquarium only when disturbed and sank when they stopped swimming. They spent much time on the bottom of the aquarium tank. These juveniles have a very narrow stomach (proventriculus) and intestine that traverse a mass of lipid-filled digestive gland, occupying the cephalothoracic region and extending back to the third abdominal segment. The stomach is smaller than that of the adults (cf. Segonzac et al., 1993). In the experiments with films of glass beads and carborundum 
powder on the bottom of dishes, none of the glass beads and very few of the sharp edged carborundum particles were seen in the guts of the juveniles, even after $20 \mathrm{~h}$. Their stomachs contained a mixture of granular black particles and amorphous organic material, presumably ingested before capture. The mid gut sometimes held a small quantity of material similar to that in the stomach but the hind gut was empty. Thus, these juvenile $R$. exoculata do have a functional gut, but half of their internal volume is occupied by the lipid-filled digestive gland, which can probably provide most of the nourishment required at this stage.

\section{DISCUSSION}

Data are now available on hydrothermal shrimp biology that allow consideration of differences between species and between sites on the Mid-Atlantic Ridge, gained from samples taken on a single cruise and treated in a uniform way for carbon and nitrogen stable isotope ratios, total carbon, nitrogen and sulphur content, local microdistribution, behaviour in the field and in captivity. The results of lipid analyses (Pond et al., 2000a,b), and results from previous publications on MAR shrimp can be combined with the new data to determine their trophic ecology.

The seven sites investigated are spread out along the MAR, ranging from 857 to $3655 \mathrm{~m}$ depth, the shallowest to the north (Table 1, Figure 1). Ambient temperature and quantity of organic sedimentation both decrease as the depth increases. The hydrothermal fluids vary in maximum temperature, dissolved sulphide and methane concentrations and these may affect the local distribution of shrimp species and their food organisms.

Stable isotope ratios have been increasingly used to identify food sources and to trace trophic pathways (see Rau et al., 1983; Fry \& Sherr, 1984; Owens, 1987; Conway et al., 1994; Vander Zanden \& Rasmussen, 1999, for references). Stable carbon isotope ratios $\left(\delta^{13} \mathrm{C}\right)$ usually show little or no enrichment of the heavy isotope $(<1 \%)$ for each trophic level and can help to identify food sources whose $\delta^{13} \mathrm{C}$ is known. In contrast, stable nitrogen isotopes $\left(\delta^{15} \mathrm{~N}\right)$ usually become enriched by $3-5 \%$ at each trophic level and can show relative trophic position, again with the proviso that the nitrogen isotope ratios are known for the primary producer. This generalization may break down in unusual habitats such as the hydrothermal vents. For example, $\delta^{15} \mathrm{~N}$ ratios may show enrichment of over $6 \%$ between tubeworm primary producers and their predators (Rau, 1981) and vent primary producers may have $\delta^{15} \mathrm{~N}$ values lower than average in the marine environment (Owens, 1987). Moreover, stable carbon isotope ratios may not always agree with deduced food web structures, and there is sometimes little evidence for direct trophic links (Fisher et al., 1994; Southward et al., 1994; Fisher, 1996). In addition, vent ecosystems can contain a preponderance of chemosynthetic bacteria that fix $\mathrm{CO}_{2}$ by means of type II ribulosebisphosphate carboxylase, which discriminates less than does type I against ${ }^{13} \mathrm{C}$ (Van Dover \& Fry, 1989, 1994; Robinson \& Cavanaugh, 1995).

The proposed main food sources for the MAR vent shrimp, and their isotope signatures are: (a) bacteria growing on the mouthparts that use the enzyme RubisCo type II to fix $\mathrm{CO}_{2}\left(\delta^{13} \mathrm{C}-8\right.$ to $-11 \%$ ); (b) free-living sulphur-oxidizing bacteria that use RubisCo type I, taken up by grazing or filtration $\left(\delta^{13} \mathrm{C}-18\right.$ to $-29 \%$ ); (c) descending pelagic material containing carbon fixed in the euphotic zone by photosynthetic organisms using RubisGo type I $\left(\delta^{13} \mathrm{C}-22 \%\right.$ and $\delta^{15} \mathrm{~N} 6 \%$, (H. Kennedy, personal data), for large volume net samples taken at $\left.24^{\circ} \mathrm{N} 24^{\circ} \mathrm{W}\right)$; (d) benthic particulate organic matter $\left(\delta^{13} \mathrm{C}\right.$ -17 to $20 \%$ ); (e) organic matter derived from hydrothermal vent molluscs that harbour symbiotic sulphuroxidizing bacteria employing RubisCo type I to fix $\mathrm{CO}_{2}$ $\left(\delta^{13} \mathrm{C}-32\right.$ to $-34 \%$ ); (f) organic matter derived from hydrothermal vent bivalves (Bathymodiolus spp.) that harbour both sulphur-oxidizing and methanotrophic bacteria ( $\delta^{13} \mathrm{C}$ varying from -14 to $-34 \%$ o).

Interpretation of the isotope data is complicated by lack of information on isotope ratios of some of the carbon sources, therefore some caveats need to be expressed. The analyses presented here show not only considerable individual variation, but also covariance between $\delta^{13} \mathrm{C}, \delta^{15} \mathrm{~N}$ and the $\mathrm{C}: \mathrm{N}$ ratio. The relative proportion of lipid, protein and carbohydrate can strongly influence the isotopic composition of bulk samples. This may obscure the expected stepwise increase in $\delta^{15} \mathrm{~N}$ between first, second and third level consumers (Vander Zanden \& Rasmussen, 1999; Vander Zanden et al., 1999; Stapp et al., 1999). As a result, it is not always easy to distinguish dietary differences. It is necessary to allow for enrichment in ${ }^{13} \mathrm{C}$ with decreasing $\mathrm{C}: \mathrm{N}$ ratio, an effect of decreased lipid content, while animals with high lipid content often have markedly negative bulk $\delta^{13} \mathrm{C}$ values, reflecting the isotopic depletion of the lipid component.

The bresilioid shrimps living on the MAR possess a range of morphological, anatomical and physiological adaptations to the hydrothermal environment, as well as different patterns of behaviour and micro-distribution. (Segonzac et al., 1992, 1993; Casanova et al., 1993; Charmantier-Daures \& Segonzac, 1997; Gebruk et al., 1997a; Lallier \& Truchot, 1997; Negre-Sadargues et al., 1997; Jinks et al., 1998; Lallier et al., 1998). A transitional series has been demonstrated, from Alvinocaris, closest in appearance to non-vent bresilioid shrimps, to the highly specialized Rimicaris, (Vereshchaka, 1996a,b; Gebruk et al., 1997a). The concept of an evolutionary series is supported by the deduced evolution of eyes in bresilioid shrimps (Gaten et al., 1998). The morphological differences are accompanied by dietary differences, so each species will be discussed separately, after noting some general features.

From evidence now available, all the hydrothermal shrimp species on the MAR pass through a juvenile pelagic phase whose food originates from photosynthetic carbon fixation in the euphotic zone. The length of the pelagic phase and the nature of the feeding mechanism, whether predation or filtration of particles, are unknown. Bathypelagic caridean shrimps generally have nonfeeding zoeal stages and their juveniles feed on zooplankton (Omori, 1974). The juvenile vent shrimp colonize the vents at lengths ranging from 14 to $25 \mathrm{~mm}$, carrying abundant stores of lipids. The change in trophic strategy then differs between the species. 
Two of the species studied, R. exoculata and C.chacei, develop 'gardens' of filamentous bacteria on their mouthparts and other surfaces inside the carapace chamber after arrival at the vents. The others investigated, Mirocaris spp. and Alvinocaris spp. do not develop 'gardens' of bacteria, though they may carry a few bacterial filaments. We discuss these groups separately.

\section{Rimicaris}

Rimicaris exoculata is the most specialized vent shrimp (Gebruk et al., 1993; Segonzac, 1992; Segonzac et al., 1993; Van Dover, 1995; reviewed by Gebruk et al., 1997a). Since the first evidence for a bacterial diet (Van Dover et al., 1988) investigations have focused on the role of the epibiotic bacteria vs free-living bacteria. The proposal by Van Dover et al. (1988) of grazing on the surface of sulphide chimneys, where free-living micro-organisms occur, was suggested by the presence of sulphide crystals in the shrimp foreguts, but ingestion of epibionts was also deemed likely. A symbiotic relationship with the filamentous bacteria that colonize the shrimp mouthparts and the undersurface of the carapace was suggested by Gebruk et al. (1992, 1993), and Segonzac et al. (1993) based on morphological and behavioural adaptations. Casanova et al. (1993) suggested that DOM from the bacteria might be absorbed by the maxillipeds. Crustacean cuticular fragments were found in the gut of one R. exoculata (Segonzac et al., 1993). An analysis of digestive enzymes (Ravellec \& van Wormhoudt, 1997) suggested a low level potential for necrophagy. Recent work has stressed the importance of the epibiotic bacteria to $R$. exoculata, although the idea of symbiotic autotrophic bacteria in the gut was also introduced (Pond et al., 1997b; Polz et al., 1998).

The present results for $R$. exoculata show a graded increase in the proportion of ${ }^{13} \mathrm{C}$ from the juveniles, through the smaller adults, to the older specimens, corresponding to the development of bacterial growths on the maxillipeds. There is also an increase in the proportion of the heavy isotope of nitrogen between the juvenile and adult stages. If these trends are considered together with the data from lipids (Pond et al., 2000a,b), then there is evidently a change in the diet during metamorphosis and maturation. The juveniles reach the vents with reserves from photosynthetic sources which fuel the immediate metabolism of the growing shrimp. Our $\delta^{13} \mathrm{C}$ results for mouthparts (maxilliped I) covered with epibiotic bacteria $(-10.52$ and $-11.45 \%)$ are close to previously reported values for shrimp epibionts, $\left(\delta^{13} \mathrm{C}-9.4\right.$ and $-12.3 \%$; Polz et al., 1998) and values for bacteria filtered from the water in a slurp-gun container that had been filled with $R$. exoculata, presumed to be detached epibiotic bacteria ( -8.6 to $-10.2 \%$; Gebruk et al., 1997b). These values indicate that the epibiotic bacteria are sulphur-oxidizers that employ type II RubisCo and the correspondence between their isotope ratios and the ratios in the tissues of adult Rimicaris from all of the MAR sites studied underlines the nutritional role of the bacteria. The similarity of $\delta^{13} \mathrm{C}$ values for adult $R$. exoculata, from shallower sites (Lucky Strike, $\sim 1700 \mathrm{~m}$ ) and the much deeper sites (Snake Pit, TAG, Broken Spur), where there will be lesser input of photosynthetic detritus, also stresses the importance of the epibiotic bacteria. Analysis of lipids of adult $R$. exoculata, of their epibiotic bacteria and of freeliving bacteria also indicates the role of the epibionts (Rieley et al., 1996; Pond et al., 1997a, in press; Allen Copley et al., 1998).

The similarity of $\delta^{13} \mathrm{C}$ values for adults from all sites does not indicate any local restriction in availability of $\mathrm{CO}_{2}$, as was previously proposed to account for $\delta^{13} \mathrm{C}$ values of -9 to $-11 \%$ in some vent organisms (Van Dover \& Fry, 1989; Fisher, 1990; Fisher et al., 1992; Kennicutt et al., 1992; Childress et al., 1993; Southward et al., 1994). Isotope and lipid data would not distinguish between ingestion of bacterial filaments and trans-epidermal transfer of DOM. However, studies of other Crustacea have shown that active transport of DOM across the chitinous exoskeleton is unlikely (Stephens, 1988).

Polz et al. (1998) used mass balance calculations, based on carbon isotope values of shrimp tissue, organic material from sulphide deposits and the epibionts, to estimate the proportion of carbon from different sources. They calculated that over $80 \%$ of the carbon in larger $R$. exoculata was provided by their epibionts, whereas smaller stages were thought to obtain $30 \%$ of their carbon by grazing on the sulphide rock surfaces. These authors did not have data for the lipid reserves of photosynthetic origin that were demonstrated subsequently (Pond et al., 1997a,b,c, 1998, 2000a,b). The presence of photosynthetic carbon explains the difference between the smaller and larger animals; partial retention to the adult would explain any difference between the bacterial food source and the tissues.

It is an open question whether adult $R$. exoculata can take up bacteria from the substratum. The chamber formed by the enlarged carapace (Segonzac et al., 1993), is nearly closed ventrally, leaving little space for manipulation of the appendages outside. Rimicaris exoculata are not attracted by the coating of filamentous bacteria that may occur within a few metres of the swarms (on rocks, mussel shells, polychaete tubes, etc.), where these occur in areas not exposed to diffuse venting fluid. The free-living bacteria in the micro-habitat favoured by adult $R$. exoculata are usually inconspicuous (Gebruk et al., 1993; Segonzac et al., 1993; Polz et al., 1998), though Polz \& Cavanaugh (1995) found filamentous forms comparable to those that grow on the shrimp. We did not see any signs of active grazing by adult $R$. exoculata on the surface of sulphide deposits. The organic material scraped from sulphide deposits at Snake Pit by Polz et al. (1998), had a $\delta^{13} \mathrm{C}$ of -22 to $-17.8 \%$ (mean $-20.66 \%$ ) and a $\delta^{15} \mathrm{~N}$ of -1 to $-3.5 \%$ (mean 2.0\%o). The results presented here for bacterial mats show a range of $\delta^{13} \mathrm{C}$ from -23 to $-29 \%$ and a $\delta^{15} \mathrm{~N}$ of $-7 \%$. All these figures are quite different from the stable isotope values of the epibionts and the tissues of Rimicaris, indicating that the bacteria on the sulphide rock surfaces are of little nutritional importance to adult $R$. exoculata.

Polz et al. (1998) found that active autotrophic bacteria in the gut of $R$. exoculata were isotopically similar to but genetically distinct from the epibionts and suggested that they might also contribute to nutrition. A bacterial microflora occurs in the guts of many marine organisms, including deep-sea animals (Deming et al., 1981; De Ridder et al., 1985; Temara et al., 1993). However, the main role of 
intestinal sulphur-oxidizing bacteria in benthic invertebrates is detoxification (Plante et al., 1990) or provision of essential dietary components (Pond et al., 1997a).

Adult $R$. exoculata avoid the hottest parts of the black smokers. The temperatures among swarms range from slightly over 10 to $30^{\circ} \mathrm{C}$, but at times may reach $40^{\circ} \mathrm{C}$ (Gebruk et al., 1993; Segonzac et al., 1993; Van Dover, 1995; Segonzac et al., 1997). Wirsen et al (1993) believe that mesophilic temperatures $\left(>20^{\circ} \mathrm{C}\right)$ are important for $\mathrm{CO}_{2}$-fixation by the epibiotic bacteria. The shrimp may seek such temperatures, aided by the greatly modified eyes that can detect radiation from the heated effluents and by chemosensory receptors for sulphide (Van Dover et al., 1989; Gaten et al., 1998; Jinks et al., 1998). It is difficult to see how this search for suitable vent fluid flow is driven, even by combined use of visual and chemosensory cues. There would be a lag in growth of the bacterial filaments that could hardly be related by the shrimp to its environment.

Patches of juvenile Rimicaris usually occur away from the zones of higher temperature. They are relatively slow moving and may not feed. Pelagic juveniles of $R$. exoculata have been collected both near vent fields and farther away (Herring \& Dixon, 1998; Herring, 1998). Their lengths range from 14 to $28 \mathrm{~mm}$. Our $\delta^{13} \mathrm{C}$ values for juveniles at vent sites suggest that the critical size for finding vent habitats lies between 18 and $25 \mathrm{~mm}$ length.

\section{Chorocaris}

Much of the carbon in adult C.chacei is derived from chemosynthetic bacteria (RubisCo type II), as in $R$. exoculata. Juveniles arrive at the vents carrying reserves of photosynthetic origin (Pond et al., 1997a), as confirmed by our isotope ratios for $16-18 \mathrm{~mm}$ length specimens $\left(\delta^{13} \mathrm{C}\right.$ as low as $-18.03 \%$ ).

Chococaris chacei resembles $R$. exoculata in carrying dense growths of filamentous bacteria on the mouthparts (Casanova et al., 1993), although the area available is smaller than in R. exoculata. Bacterial growths are evident on juveniles of $C$. chacei $16-19 \mathrm{~mm}$ long. The small adults (23-42 mm) show a mean $\delta^{13} \mathrm{C}$ of $-12.77 \%$ (Table 2), indicating that there is a strong input of carbon from bacterial sources (type II RubisCo). In contrast, the larger adults of C. chacei are often found within (or close to) swarms of R. exoculata and can act as predators or scavengers on the latter. This behaviour is confirmed by the presence of mouthparts of $R$. exoculata in the stomach of C.chacei (Segonzac et al., 1993; A. Gebruk, personal observations).

In theory, nitrogen isotope ratios might indicate whether C.chacei feed on adult R. exoculata. C.chacei from Lucky Strike are in fact more depleted in ${ }^{15} \mathrm{~N}$ than adult $R$. exoculata there. At the deeper stations the C.chacei are slightly more enriched in ${ }^{15} \mathrm{~N}$ than the $R$. exoculata, but the difference is less than $0.5 \%$. Thus adult $R$. exoculata cannot be a major source of nitrogenous food for C.chacei. However, the juveniles of $R$. exoculata have a mean $\delta^{15} \mathrm{~N}$ some $1.6 \%$ lower than the mean for $C$. chacei, leaving open the possibility that this stage of $R$. exoculata is a source of food for adult $C$. chacei.

The carbon isotope ratios for C. chacei do not discriminate between feeding on epibiotic bacteria and scavenging among R.exoculata swarms. The trophic changes in growing C.chacei are thus more difficult to interpret. The juveniles arrive at the vents with reserves of photosynthetic origin, as does $R$. exoculata. At an intermediate size, before reaching the full adult stage, they must rely heavily on the epibiotic bacteria on the mouthparts. In the adult stages, where scavenging or occasional predation on $R$. exoculata may occur, there is still considerable input from the epibiotic bacteria.

\section{Alvinocaris}

Alvinocaris spp. are opportunistic feeders. The distribution of $A$. markensis adults (present study and Segonzac et al., 1993) shows little correlation with that of $R$. exoculata. Alvinocaris markensis is most common at the periphery of vent communities where it is likely to use a variety of food, as shown by the carbon and nitrogen isotope results (Table 2). Both A.markensis and C.chacei were seen at the Logatchev clam bed (Anya's Garden) where R. exoculata is absent. In contrast, observations at Snake Pit showed large numbers of adult A.markensis close to swarms of $R$. exoculata.

The $\delta^{13} \mathrm{C}$ for a small $(28 \mathrm{~mm})$ adult from Logatchev $(-21.17 \%$ o $) \quad$ suggests little input of chemosynthetic bacterial carbon. Taken with the large quantity of wax esters reported by Pond et al. (1997b) in post-larval A. markensis from Broken Spur, an initial photosynthetic food source is confirmed.

\section{Mirocaris}

Mirocaris spp. are opportunists that will ingest tissues of mussels, shrimp and other invertebrates when available. Mirocaris spp. are most abundant in zones of high biomass such as mussel beds, but can also be found at the periphery of the vent communities, as noted also by Vinogradov \& Vereshchaka (1995) and by Gebruk et al. (1997a). Previous studies reported a mixture of bacterial and mussel-derived material (pseudo-faeces, mucus, etc.) in the diet of M. fortunata at Lucky Strike, but the juveniles also contained material of photosynthetic origin (Pond et al., 1997c, 2000a,b). Vereschaka et al. (1997b) noted remains of $R$. exoculata in the stomach of $M$. keldysh $i$ at TAG, where there are no mussels

Both M. fortunata and M. keldyshi have a wide range of $\delta^{13} \mathrm{C}$ values. Mirocaris fortunata also showed a very wide range of $\delta^{15} \mathrm{~N}$. Bacterial carbon (RubisCo type II) occurred in specimens from certain sites, notably Rainbow and Broken Spur. Some M. fortunata from Lucky Strike showed distinctive $\delta^{13} \mathrm{C}$ values of -22.61 and $-22.06 \%$ and $\delta^{15} \mathrm{~N}$ values of -1.34 and $-2.16 \%$. These can be compared with values for free-living bacteria and bacteria plus detritus $\left(\delta^{13} \mathrm{C} \quad-29.39 \%\right.$, $-27.64 \%$, $-25.69 \% ; \delta^{15} \mathrm{~N}-7.11 \%$ ) at the site and also with the values for the dominant mussels on which the shrimp might be preying. While not excluding input from photosynthetic sources, as suggested by Pond et al. (1997c) from study of lipids, our isotope values indicate that a proportion of the carbon in M. fortunata at Lucky Strike could be derived from bacteria that use type I RubisCo, either by scavenging/predation on mussels, or by grazing on sulphide surfaces and detritus. Previous detailed 
investigations on Bathymodiolus azoricus from the shallow sites, Menez Gwen and Lucky Strike, show great variation in stable isotope ratios, consistent with varying predominance of two types of endosymbionts, thiotrophs and methanotrophs. Pond et al. (1998) determined lipid $\delta^{13} \mathrm{G}$ values ranging from -34.9 to $-24.9 \%$ in Menez Gwen mussels. Trask \& Van Dover (1999) reported two isotopically distinct communities of Bathymodiolus at Lucky Strike, one from Sintra (predominantly methanotrophic) with gill tissue $\delta^{13} \mathrm{C}$ of -25.1 to $-14.7 \%$ (mean $-22.0 \%$ ), the other from Eiffel Tower, with gill tissue $\delta^{13} \mathrm{C}$ of -33.4 to $-28.7 \%$ (mean $-31.1 \%$ ), deemed thiotrophic. The corresponding means for $\delta^{15} \mathrm{~N}$ were $-4.5 \%$ and $-10.5 \%$. The nitrogen isotope differences between Lucky Strike M. fortunata and possible food sources would thus average 11.25 (published data) to $12.95 \%$ o (our data) for thiotrophic mussels and $8.85 \%$ for bacterial mats. Adult thiotrophic mussels are thus not a major food source for M.fortunata. Trask \& Van Dover (1999) also examined larval and post-larval stages of Bathymodiolus, finding $\delta^{13} \mathrm{C}$ values from -19.9 to $-17.3 \%$ and $\delta^{15} \mathrm{~N}$ values from 0.1 to $4.4 \%$, indicating photosynthetic origin. Feeding on these juvenile mussels might better fit the nitrogen isotope values in M.fortunata, but the carbon values do not support the idea.

\section{Ecological implications}

Shrimps such as C.chacei and R. exoculata are highly specialized for carrying and cultivating their symbionts. The grooming behaviour in many decapod crustaceans has probably assisted this form of feeding (Bauer, 1989). Nevertheless, the shrimp community cannot exist on chemosynthetic sources alone. Planktonic larval feeding is needed to allow accumulation of essential unsaturated fatty acids (PUFA) required for maturation and breeding (Pond et al. 1997a,b,c; 2000a). What still remains to be determined is how the larvae obtain enough food to build up these reserves. The MAR vent communities are overlain by relatively oligotrophic surface waters where many other crustaceans, mostly carnivores, are present at depths between 800 and $3000 \mathrm{~m}$, and where the mesoplankton biomass is $<1 \mathrm{mg} \mathrm{m}^{-3}$ (Foxton, 1970; Vinogradov, 1997). This habitat is the antithesis of the rich feeding available at hydrothermal vents. However, over the hydrothermal vents at the deeper MAR sites there are local increases in plankton and particulate matter below $2000 \mathrm{~m}$ (Vinogradov et al., 1996). Corresponding enrichment has been found over vents in the north-east Pacific (Roth \& Dymond, 1989; Thomson et al., 1992; Burd \& Thomson, 1995). This near-bottom increase in biomass has been attributed to material carried up in the hydrothermal plume, but may be an accumulation of sedimenting particles of photosynthetic origin trapped by the density gradient (Vinogradov, 1997). Particulate matter above the plume could thus be the source of the PUFA required by the larval shrimp, if there is enough of it.

Gebruk et al. (1997a) believe that the large biomasses found at hydrothermal vents are linked to nutritional symbioses that support the community. The evidence reviewed here can be regarded as favouring this hypothesis. However, in several hydrothermal vent communities, the stable isotope data do not always indicate tight trophic coupling between the endosymbiont-containing 'primary producers' and other invertebrates, for example, arthropods and molluscs (Fisher et al., 1994; Fisher, 1996).

The shrimps of the Mid-Atlantic Ridge have radiated since the Miocene (Shank et al., 1999). The symbiotrophy found in R. exoculata and C. chacei seems necessary to produce the observed high population densities. The absence from the Atlantic vents of other 'primary producers', such as the symbiont-containing tube-worms, may have provided a vacant niche for exploitation by the shrimp.

The submersible work at sea in 1997, and the laboratory studies, were supported by the UK Natural Environment Research Council (NERG) through the UK BRIDGE programme (grant GST/02/1478). A.J.S. and E.C.S. thank NERC (grant GR3/8470) and the Leverhulme Trust for earlier support. A.G. acknowledges assistance from the Royal Society of London and the Humboldt Foundation, Germany. H.K. was supported by NERG grant JREI (GR3 E0068). We are indebted to Professor J.R. Cann, FRS, Professor P.A. Tyler, Dr D. Fornari and Dr K. Harrison, for arranging participation in the 'Atlantis' cruise. We thank the pilots and support team for their efforts to sustain the submersible programme. We also thank Professor R.C. Vrijenhoek and Professor R.A. Lutz for their willingness to share the second leg of the MAR 97 'Atlantis' cruise. Thanks are due to Professor P.R. Dando, Professor J.R. Sargent and Dr A.S. Clare for help and advice, to R.N. Head for the elemental analyses, and to Paul Kennedy for maintaining the stable isotope facility at Menai Bridge and for assistance in the analyses. Dr D.W. Pond and Dr T.M. Shank provided unpublished data on the lipids and genetics of the shrimp. Dr A.L. Vereshchaka advised on shrimp taxonomy. Thanks are due to Drs R. and A. Scheltema for the loan of a drying oven for preparing the samples for isotope analysis.

\section{REFERENCES}

Allen Copley, G.E., Tyler, P.A. \& Varney, M.S., 1998. Lipid profiles of hydrothermal vent shrimps. Cahiers de Biologie Marine, 39, 229-231.

Bauer, R.T., 1989. Decapod crustacean grooming: functional morphology, adaptive value, and phylogenetic significance. In Functional morphology of feeding and grooming in Crustacea (ed. B.E. Felgenhauer et al.), pp. 49-74. Rotterdam: A.A. Balkema.

Burd, B.J. \& Thomson, R.E., 1995. Distribution of zooplankton associated with the Endeavour Ridge hydrothermal plume. Journal of Plankton Research, 17, 965-997.

Casanova, B., Brunet, M. \& Segonzac, M., 1993. L'impact d'une épibiose bactérienne sur la morphologie fonctionelle de crevettes associeés a l'hydrothermalisme médio-atlantique. Cahiers de Biologie Marine, 34, 573-588.

Charmantier-Daures, M. \& Segonzac, M., 1997. Organ of Bellonci and sinus gland in three decapod crustaceans from Atlantic hydrothermal vents: Rimicaris exoculata, Chorocaris chacei and Segonzacia mesatlantica. Cahiers de Biologie Marine, 38, 116-117.

Childress, J.J. \& Fisher, C.R., 1992. The biology of hydrothermal vent animals: physiology, biochemistry, and autotrophic symbioses. Oceanography and Marine Biology. Annual Reviere, 30, 337-441.

Childress, J.J. et al., 1993. Inorganic carbon uptake in hydrothermal vent tubeworms facilitated by high environmental $p \mathrm{CO}_{2}$. Nature, London, 362, 147-149.

Christoffersen, M.L., 1986. Phylogenetic relationships between Oplophoridae, Atyidae, Pasiphaeidae, Alvinocarididae Fam. N., Bresiliidae, Psalipodidae and Disciadidae (Crustacea Caridea Atyoidea). Boletim de Zoologia Universidade São Paulo, 10, 273-281. 
Conway, N., Kennicutt, M.C. \& Van Dover, C.L., 1994. Stable isotopes in the study of marine chemosynthetically-based ecosystems. In Stable isotopes in ecology (ed. K. Lajtha and R. Michener), pp. 158-186. New York: Blackwell Scientific Publications.

Copley, J.T.R., Tyler, P.A., Murton, B.J. \& Van Dover, C.L., 1997. Spatial and annual variation in the faunal distribution at Broken Spur vent field ( $29^{\circ} \mathrm{N}$, Mid-Atlantic Ridge). Marine Biology, 129, 723-733.

Creasey, S., Rogers, A.D. \& Tyler, P.A., 1996. Genetic comparison of two populations of the deep-sea vent shrimps Rimicaris exoculata (Decapoda: Bresiliidae) from the Mid-Atlantic Ridge. Marine Biology, 125, 473-482.

De Ridder, C., Jangoux, M. \& De Vos, L., 1985. Description and significance of a peculiar intradigestive symbiosis between bacteria and a deposit-feeding echinoid. Fournal of Experimental Marine Biology and Ecology, 96, 65-75.

Deming, J.W., Tabor, P.S. \& Colwell, R.R., 1981. Barophilic growth of bacteria from intestinal tracts of deep-sea invertebrates. Microbial Ecology, 7, 85-94.

Dixon, D.R., Dixon, L.R.J. \& Pond, D.W., 1998. Recent advances in our understanding of the life history of bresiliid vent shrimps on the MAR. Cahiersde Biologie Marine, 39,383-386.

Fisher, C.R., 1990. Chemoautotrophic and methanotrophic symbioses in marine invertebrates. CRC Reviews in Aquatic Sciences, 2, 399-436.

Fisher, C.R., 1996. Ecophysiology of primary production at deepsea vents and seeps. Biosystematics and Ecology Series, 11, 313-336.

Fisher, C.R., Kennicutt, M.C. \& Brooks, J.M., 1992. Stable carbon isotopic evidence for carbon limitation in hydrothermal vent vestimentiferans. Science, New York, 247, 1094-1096.

Fisher, C.R., Childress, J.J., Brooks, J.M. \& Macko, S.A., 1994. Nutritional interactions in Galapagos Rift hydrothermal vent communities: inferences from stable carbon and nitrogen isotope analyses. Marine Ecology Progress Series, 103, 45-55.

Foxton, P., 1970. The vertical distribution of pelagic decapods (Crustacea: Natantia) collected on the SOND cruise 1965. I. The Caridea. Fournal of the Marine Biological Association of the United Kingdom, 50, 939-960.

Fry, B. \& Sherr, E.B., 1984. $\delta^{13} \mathrm{C}$ measurements as indicators of carbon flow in marine and freshwater ecosystems. Contributions in Marine Science, 27, 13-47.

Gal'chenko, V.F., Pimenov, N.V., Lein A.Y., Galkin, S.V., Moskalev, L.I. \& Ivanov, M.V., 1989. Autotrophic $\mathrm{CO}_{2}$-assimilation in tissues of the shrimp Rimicaris exoculata from hydrothermal region in the Mid-Atlantic Ridge. Doklady Akademii Nauk SSSR, 308, 1478-1481.

Gaten, E., Herring, P., Shelton, P. \& Johnson, M., 1998. Comparative morphology of the eyes of postlarval bresiliid shrimps from the region of hydrothermal vents. Biological Bulletin. Marine Biological Laboratory, Woods Hole, 194, 267-280.

Gebruk, A.V., Chevaldonné, P., Shank, T., Vrijenhoek, R.G. \& Lutz, R.A., 2000. Deep-sea hydrothermal vent communities of the Logatchev area $\left(14^{\circ} 45^{\prime} \mathrm{N}\right.$, Mid-Atlantic Ridge): diverse biotopes and high biomass. Fournal of the Marine Biological Association of the United Kingdom, 80, 383-393.

Gebruk, A.V., Galkin, S.V., Vereshchaka, A.L., Moskalev, L.I. \& Southward, A.J., 1997a. Ecology and biogeography of the hydrothermal vent fauna of the Mid-Atlantic Ridge. Advances in Marine Biology, 32, 93-144.

Gebruk, A.V., Lein, A.Y., Galkin, S.V., Miller, Y.V., Pimenov, N.V., Moskalev, L.I. \& Ivanov, M.V., 1997b. Trophic Structure of the Broken Spur hydrothermal community as revealed by stable isotope and $\mathrm{C}: \mathrm{H}: \mathrm{N}: \mathrm{S}$ data. BRIDGE Neresletter, 12, 40-44.

Gebruk, A.V., Pimenov, N.V. \& Savvichev, A.S., 1992. Bacterial "farm" on the mouthparts of shrimp. Priroda, 8, 3739. [In Russian].
Gebruk A.V., Pimenov N.V. \& Savvichev A.S., 1993. Feeding specialization of Bresiliidae shrimps in the TAG site hydrothermal community. Marine Ecology Progress Series, 98, 247-253.

Herring, P.J., 1998. North Atlantic midwater distribution of the juvenile stages of hydrothermal vent shrimps (Decapoda: Bresiliidae). Cahiers de Biologie Marine, 39, 387-390.

Herring, P.J. \& Dixon, D.R., 1998. Extensive deep-sea dispersal of postlarval shrimp from a hydrothermal vent field. Deep-Sea Research, 45, 2105-2118.

Jinks, R.N., Batelle, B.-A., Herzog, E.D., Kass, L., Renninger, G.H. \& Chamberlain, S.C., 1998. Sensory adaptations in hydrothermal vent shrimps from Mid-Atlantic Ridge. Cahiers de Biologie Marine, 39, 309-312.

Kennicutt, M.C., Burke, R.A., MacDonald, I.R., Brooks, J.M., Denoux, G.J. \& Macko, S.A., 1992. Stable isotope partitioning in seep and vent organisms: chemical and ecological signifigance. Chemical Geology (Isotope Geosciences Section), 101, 293-310.

Lallier, F.H., Camus, L., Chausson, F. \& Truchot, J.-P., 1998. Structure and function of hydrothermal vent crustacean haemocyanins: an update. Cahiers de Biologie Marine, 39, 313-316.

Lallier, F.H. \& Truchot, J.-P., 1997. Haemocyanin structure and function in alvinocaridean shrimps. Cahiers de Biologie Marine, 38, 130.

Maas, P.A.Y., O’Mullen, G.D., Lutz, R.A. \& Vrijenhoek, R.G., 1999. Genetic and morphometric characterization of mussels (Bivalvia: Mytilidae) from Mid-Atlantic hydrothermal vents. Biological Bulletin. Marine Biological Laboratory, Woods Hole, 196, 265-272.

Martin, J.W. \& Christiansen, J.C., 1995. A new species of the shrimp genus Chorocaris Martin and Hessler 1990, from hydrothermal vents along the Mid-Atlantic Ridge. Proceedings of the Biological Society of Washington, 108, 220-227.

Martin, J.W., Signorovitch, J. \& Patel, H., 1997. A new species of Rimicaris (Crustacea: Decapoda: Bresiliidae) from the Snake Pit hydrothermal vent field on the Mid-Atlantic Ridge. Proceedings of the Biological Society of Washington, 110, 399-411.

Negre-Sadargues, G., Segonzac, M. \& Castello, R., 1997. Carotenoid pigments and trophic behaviour of Crustacea from the Snake Pit hydrothermal area (Mid-Atlantic Ridge, $\left.23^{\circ} \mathrm{N}\right)$. Cahiers de Biologie Marine, 38, 134-135.

Omori, M., 1974. The biology of pelagic shrimps in the ocean. Advances in Marine Biology, 12, 233-324.

Owens, N.J.P., 1987. Natural variation in ${ }^{15} \mathrm{~N}$ in the marine environment. Advances in Marine Biology, 24, 390-451.

Plante, C., Jumars, P.A. \& Baross, J.A., 1990. Digestive associations between marine detritovores and bacteria. Annual Reviews in Ecology and Systematics, 21, 93-127.

Polz, M.F. \& Cavanaugh, C.M., 1995. Dominance of one bacterial species at a Mid-Atlantic Ridge hydrothermal vent site. Proceedings of the National Academy of Sciences of the United States of America, 92, 7232-7236.

Polz, M.F., Robinson, J.J., Cavanaugh, C.M. \& Van Dover, C.L., 1998. Trophic ecology of massive shrimp aggregations at a Mid-Atlantic Ridge hydrothermal vent site. Limnology and Oceanography, 43, 1631-1638.

Pond, D.W., Bell, M.V., Dixon, D.R., Fallick, A.E., Segonzac, M. \& Sargent, J.R., 1998. Stable-carbon-isotope composition of fatty acids in hydrothermal vent mussels containing methanotrophic and thiotrophic bacterial endosymbionts. Applied and Environmental Microbiology, 64, 370-375.

Pond, D.W., Dixon, D.R., Bell, M.V., Fallick, A.E. \& Sargent, J.R., 1997a. Occurence of 16:2(n-4) and 18:2(n-4) fatty acids in the lipids of the hydrothermal vent shrimps Rimicaris exoculata and Alvinocaris markensis: nutritional and trophic implications. Marine Ecology Progress Series, 156, 167-174. 
Pond, D.W., Dixon, D.R \& Sargent, J.R., 1997b. Wax-ester reserves facilitate dispersal of hydrothermal vent shrimps. Marine Ecology Progress Series, 156, 289-290.

Pond, D.W., Gebruk, A., Southward, E.C., Southward, A.J., Fallick, A.E., Bell, M.V. \& Sargent, J.R., 2000b. Unusual fatty acid composition of storage lipids in the bresilioid shrimp, Rimicaris exoculata, couples the photic zone with MAR hydrothermal vent sites. Marine Ecology Progress Series, in press.

Pond, D.W., Sargent, J.R., Fallick, A.E., Allen, C., Bell, M.V. \& Dixon, D.R., 2000a. $\delta^{13} \mathrm{C}$ values of lipids from phototrophic zone microplankton and bathypelagic shrimps at the Azores sector of the Mid-Atlantic Ridge. Deep-Sea Research, 47, 121-136.

Pond, D.W., Segonzac, M., Bell, M.V., Dixon, D.R., Fallick, A.E. \& Sargent, J.R., 1997c. Lipid and lipid carbon stable isotope composition of the hydrothermal vent shrimp Mirocaris fortunata: evidence for nutritional dependence on photosynthetically fixed carbon. Marine Ecology Progress Series, 157, 221-231.

Rau, G.H., 1981. Low ${ }^{15} \mathrm{~N} /{ }^{14} \mathrm{~N}$ in hydrothermal vent animals: ecological implications. Nature, London, 289, 484-485.

Rau, G.H., Mearns, A.J., Young, D.R., Olson, R.J., Schafer, H.A. \& Kaplan, I.R., 1983. Animal ${ }^{13} \mathrm{C} /{ }^{12} \mathrm{C}$ correlates with trophic level in pelagic food webs. Ecology, 64, 1314-1318.

Ravellec, R. \& Van Wormhoudt, A., 1997. Evolution of digestive enzyme activities and structures in Alvinocarididae shrimps. Cahiers de Biologie Marine, 38, 136-137.

Rieley, G., Van Dover, C.L., Hedrick, D.B. \& Eglinton, G., 1996. Trophic ecology of Rimicaris exoculata from TAG as revealed by relative abundance and isotopic compositions of individual fatty acids. Fournal of Conference Abstracts, 1, 846-847.

Robinson, J.J. \& Cavanaugh, V.M., 1995. Expression of form I and form II Rubisco in chemoautotrophic symbioses: Implications for the interpretation of stable carbon isotope values. Limnology and Oceanography, 40, 1496-1502.

Rona, P., Klinkhammer, G., Nelsen, T.A., Trefry, J.H. \& Elderfield, H., 1986. Black smokers, massive sulfides and biota at the Mid-Atlantic Ridge. Nature, London, 312, 33-37.

Roth, S.E. \& Dymond, J., 1989. Transport and settling of organic material in a deep-sea hydrothermal plume: evidence from particle flux measurments. Deep-Sea Research, 36, 12371254.

Segonzac, M., 1992. Les peuplements associés à l'hydrothermalisme océanique du Snake Pit (dorsale médio-atlantique; $23^{\circ} \mathrm{N}, 3480 \mathrm{~m}$ ): composition et microdistribution de la mégafaune. Comptes Rendus de l'Académie des Sciences de Paris. Sér. III, 314, 593-600.

Segonzac, M., Comtet, T. \& Chevaldonné, P., 1997. Epibiosis in two invertebrate species associated to oceanic hydrothermalism: an example of adaptive convergence. Cahiers de Biologie Marine, 38, 139-140.

Segonzac M, Saint Laurent, M. de \& Casanova, B., 1993. L'énigme $\mathrm{du}$ comportement trophique des crevettes Alvinocarididae des sites hydrothermaux de la dorsale médioatlantique. Cahiers de Biologie Marine, 34, 535-571.

Shank, T.M., Black, M.B., Halanych, K.M., Lutz, R.A. \& Vrijenhoek, R.C., 1999. Miocene radiation of deep-sea hydrothermal vent shrimp (Caridea: Bresiliidae): evidence from mitochondrial Cytochrome Oxidase subunit I. Molecular Phylogenetics and Evolution, 13, 244-254.

Shank, T.M., Lutz, R.A. \& Vrijenhoek, R.C., 1998. Molecular systematics of shrimp (Decapoda: Bresiliidae) from deep-sea hydrothermal vents. I. Enigmatic "small orange" shrimp from the Mid-Atlantic Ridge are juvenile Rimicaris exoculata. Molecular Marine Biology and Biotechnology, 7, 88-96.

Southward, A.J., Southward, E.C., Spiro, B., Rau, G.H. \& Tunnicliffe, V., $1994 .{ }^{13} \mathrm{C} /{ }^{12} \mathrm{C}$ of organisms from the Juan de Fuca Ridge hydrothermal vents: a guide to carbon and food sources. Fournal of the Marine Biological Association of the United Kingdom, 74, 265-278.
Stapp, P., Polls, G.A. \& Piñero, F.S., 1999. Stable isotopes reveal strong marine and El Niño effects on island food webs. Nature, London, 401, 467-469.

Stephens, G.C., 1988. Epidermal amino acid transport in invertebrates. Biochimica et Biophysica Acta, 947, 113-138.

Temara, A., De Ridder, C., Kuenen, J.G. \& Robertson, L.A., 1993. Sulfide-oxidizing bacteria in the burrowing echinoid, Echinocardium cordatum (Echinodermata). Marine Biology, 115, 179-185.

Thomson, R.E., Burd B.J., Dolling, A.G., Gordon, L.R. \& Jamieson, G.S., 1992. The deep scattering layer associated with the Endeavour Ridge hydrothermal plume. Deep-Sea Research, 39, 55-73.

Trask, J.L. \& Van Dover, C.L., 1999. Site-specific and ontogenetic variations in nutrition of mussels (Bathymodiolus sp.) from the Lucky Strike hydrothermal vent field, Mid-Atlantic Ridge. Limnology and Oceanography, 44, 334-343.

Vander Zanden, M.J., Casselman, J.M. \& Rasmussen, J.B., 1999. Stable isotope evidence for the food web consequences of species invasions in lakes. Nature, London, 401, 464-467.

Vander Zanden, M.J. \& Rasmussen, J.B., 1999. Primary consumer $\delta^{13} \mathrm{C}$ and $\delta^{15} \mathrm{~N}$ and the trophic position of aquatic consumers. Ecology, 80, 1395-1404.

Van Dover, C.L., 1995. Ecology of Mid-Atlantic Ridge hydrothermal vents. In Hydrothermal vents and processes (ed. L.M. Parson et al.), pp. 257-294. London: Geological Society. [Special Publication.]

Van Dover, C.L. \& Fry, B., 1989. Stable isotopic compositions of hydrothermal vent organisms. Marine Biology, 102, 257-263.

Van Dover, C.L. \& Fry, B., 1994. Microorganisms as food resources at deep-sea hydrothermal vents. Limnology and Oceanography, 39, 51-57.

Van Dover, C.L., Fry, B., Grassle, J.F., Humphris, S. \& Rona, P.A., 1988. Feeding biology of the shrimps Rimicaris exoculata at hydrothermal vents on the Mid-Atlantic Ridge. Marine Biology, 98, 202-216.

Van Dover, C.L., Szuts, E.Z., Chamberlain, S.G. \& Cann, J.R., 1989. A novel eye in 'eyeless' shrimp from hydrothermal vents of the Mid-Atlantic Ridge. Nature, London, 337, 458-460.

Vereshchaka, A.L., 1996a. A new genus and species of caridean shrimp (Crustacea: Decapoda: Alvinocarididae) from North Atlantic hydrothermal vents. Fournal of the Marine Biological Association of the United Kingdom, 76, 951-961.

Vereshchaka, A.L., 1996b. Comparative analysis of taxonomic composition of shrimps as edificators of hydrothermal communities on the Mid-Atlantic Ridge. Doklady Akademii Nauk, 351, 134-136. [In Russian.]

Vereshchaka, A.L., 1997a. A new family for a deep-sea caridean shrimp from North Atlantic hydrothermal vents. Journal of the Marine Biological Association of the United Kingdom, 77, 425-438.

Vereshchaka, A.L., 1997b. Comparative morphological studies on four populations of the shrimp Rimicaris exoculata from the Mid-Atlantic Ridge. Deep-Sea Research I, 44, 1905-1921.

Vinogradov, M.E., 1997. Some problems of vertical distribution of meso- and macroplankton in the ocean. Advances in Marine Biology, 32, 1-92.

Vinogradov, M.E \& Vereshchaka, A.L., 1995. The micro-scale distribution of the hydrothermal near-bottom shrimp fauna. Deep-Sea Newsletter, 23, 18-21.

Vinogradov, M.E., Vereshchaka, A.L. \& Shushkina, E.A., 1996. Vertical structure of the zooplankton communities in the oligotrophic areas of the North Atlantic and influence of the hydrothermal vents. Okeanologia, 36, 71-79. [In Russian.]

Von Cosel, R., Comtet, T. \& Krylova, E.M., 1999. Bathymodiolus (Bivalvia: Mytilidae) from hydrothermal vents on the Azores Triple Junction and the Logatchev hydrothermal field, MidAtlantic Ridge. The Veliger, 42, 218-248. 
Williams, A.B., 1988. New marine decapod crustaceans from waters influenced by hydrothermal discharge, brine and hydrocarbon seepage. Fisheries Bulletin, 86, 263-287.

Williams, A.B. \& Rona, P.A., 1986. Two new caridean shrimps (Bresiliidae) from a hydrothermal vent field on the MidAtlantic Ridge. Fournal of Crustacean Biology, 6, 446-462.
Wirsen, C.O., Jannasch, H.W. \& Molyneaux, S.J., 1993. Chemosynthetic microbial activity at Mid-Atlantic Ridge hydrothermal vent sites. Fournal of Geophysical Research, 98, 9693-9703.

Submitted 24 January 2000. Accepted 28 February 2000. 